\title{
Relation of project managers' personality and project performance: An approach based on value stream mapping
}

\author{
Maurizio Bevilacqua, Filippo Emanuele Ciarapica, Michele Germani, Giovanni Mazzuto, \\ Claudia Paciarotti \\ Department of Industrial Engineering Università Politecnica delle Marche (Italy) \\ m.bevilacqua@univpm.it,..ciarapica@univpm.it,.m.germani@univpm.it,..mazzuto@univpm.it,.c.paciarotti@.univpm.it
}

Received: November 2013

Accepted: July 2014

\section{Abstract:}

Purpose: This work investigates the influence of project managers' personality on the success of a project in a Multinational Corporation. The methodology proposed for analyzing the project managers' personality is based on the Myers-Briggs Type Indicator.

Design/methodology: Forty projects carried out in 2012 by multinational corporation, concerning new product development (NPD), have been analyzed, comparing the profile of project managers with results obtained in terms of traditional performance indexes (time delay and over-budget of projects) and performance indexes usually used in "Lean Production" sector (waste time and type of "wastes"). A detailed analysis of the most important "wastes" during the project development is carried out using the Value Stream Mapping (VSM) technique.

Findings: Relying on the Myers-Briggs personality instrument, results show that extroverted managers (as opposed to introverted managers) carry out projects that show lower delay and lower waste time. Introverted managers often make "Over-processing" and "Defect" types of waste. Moreover, lower delay and over-budget have been shown by perceiving managers.

Research limitations/implications: Regarding the limitations of this work it is necessary to highlight that we collected data from project managers in a retrospective way. While we believe 
that several aspects of our data collection effort helped enhance the accuracy of the results, future research could conduct real-time case study research to get more detailed insights into the proposed relationships and avoid retrospective bias. Moreover we focused on a single respondent, the project manager. This helped us ensure that their interpretations played an important role in product development. But, we cannot examine the opinion of team members that could be different from project manager's opinion regarding some questions.

Originality/value: This research provides insight useful to develop proactive approaches to prevent project failures, including the creation of more effective messages and methods to help companies to make the best choices during managers' hiring. Moreover this research would allow organizations to better match the short-term organizational needs with appropriate personality types.

Keywords: Project managers' personality, Myers-Briggs type indicator, value stream mapping, project performance, New Product Development (NPD)

\section{Introduction}

Several researchers highlighted a relation between project managers' personality and project performance. According to Purcell and Hutchinson (2007) the personality of project managers plays a significant role in the projects' outcome, especially when the project concerns the new product development (NPD). The leadership and the interpersonal skills of project managers are the most important key factors that lead a project to be successful (Othman, Gouw \& Bhuiyan, 2012). It is therefore more productive to preselect innovative, creative people for the early stages of a project, and then teach this group the business discipline required in stagegate NPD processes. Crawford (1987) suggested that market research supporting early stage NPD project analysis is often not done very well because the individuals usually selected are risk averse, patient, and persistent individuals, whereas market research for NPD requires personnel with high risk acceptance, creativity, and openness to the "irrational" process of NPD. Researchers have long debated the skills and competencies (Gehring, 2007) that are beneficial in the project manager role that may reduce project failures (Gillard \& Price, 2005). Jablokow and Booth (2006) introduced the concepts of cognitive gaps to explain the source of problems in new projects. First, differences between the nature and difficulty of the problem at hand and the cognitive resources of the problem solvers tasked with its solution; and second, differences between the cognitive abilities and approaches of the problem solvers themselves.

In this context, this work investigates the relation, if it exists, between the project managers' personality and success of a project in a Multinational Corporation. Managers' personality is 
analyzed using the Myers-Briggs Type Indicator (MBTI) method while project performance is assessed using two traditional indexes (project delay and over-budget) and two indexes used in lean production management: waste time and waste type. The last two indexes, never used in project management field, have been defined in this work using an approach based on Value Stream Mapping (VSM) techniques. This research would allow Multinational Corporation to prevent project failures making the best choices during managers' hiring.

The paper is organized as follows: section 2 is divided into two parts. Section 2.1 presents a brief overview of MBTI and a review of the relevant literature on the use of MBTI in the determination of managers' personalities (section 2.1.1). Moreover, section 2.1 .2 briefly describes the Value Stream Mapping tools used in this work. The second part of section 2 analyses the literature about the influence of project managers' personality on project performance and develops the research hypothesis. Section 3 describes the procedure carried out to collect and to analyze data. In Section 4, results of data analysis are presented. Finally, discussion and conclusions are presented in sections 5 and 6.

\section{Hypothesis development}

\subsection{Background}

\subsubsection{Personality type and Myers Briggs Type Indicator}

Various testing methods for classifying individuals have been developed in the past. The most important tests of personality type include the Rorschach ink blot test, the Thematic Apperception Test (TAT), the Myers-Briggs Type Indicator (MBTI), and the Big Five personality trait taxonomy, among many others. The TAT and Rorschach are projective tests, i.e. the assessment of the subject is based on what the individual projects on a given image (Dolfi \& Andrews, 2007). The Big Five personality traits overlap with some MBTI classifications and are comprised of openness, conscientiousness, extroversion, agreeableness and neuroticism.

According to Dolfi and Andrews (2007), project managers have certain functional characteristics associated with their work environment that lend themselves well to MBTI classification. The MBTI Form $M$ is a forced-choice, self-disclosure instrument that has been administered more than 2 million times yearly, making it the most administered personality profile (Myers \& Myers, 1980). Based on Jung's theory of psychological types, the MBTI contains four dichotomous scales and each category presents two polar opposites. They are:

- where a person focuses his or her attention: extroversion (E) and introversion (I),

- the way a person gathers information: sensing (S) and intuition (N),

- the way a person makes decisions: thinking $(T)$ and feeling $(F)$, and 
- how a person deals with the outer world: judging $(\mathrm{J})$ and perceiving $(\mathrm{P})$. For example, a person could be MBTI profiled with INFJ. This means the person has a tendency towards introversion, intuition, feeling, and judging.

Extraverted individuals obtain information through an orientation toward the outer world of people, events, or things. They enjoy meeting new people, thinking aloud, and being active. Introversion types seek the introspection of ideas, thoughts, and concepts. They prefer to process their thoughts internally before speaking, have few close friends, and often seek conversations that tend to be deeper in nature.

Sensing (S) and Intuition (N) refers to how information from the external world is understood and interpreted by individuals. Sensing types are more aware of their senses in relation to their environment; they are often factually based, focus on practical, concrete problems, and they generally believe that if something works, it is best to leave it alone. Individuals who have a tendency to understand the world through an Intuitive process prefer to live in a world of possibilities and options and to look towards the future. They also tend to focus on complicated abstract problems, seeing the big picture, sometimes at the expense of details (Hirsh \& Kummerow, 1997).

Thinking ( $T$ ) and Feeling ( $F$ ) are considered the "rational processes" by which we come to certain conclusions and judgments regarding the gathered information. Thinking types ( $T$ ) prefer to make decisions based on an impersonal objective position. Feeling types ( $F)$ have a tendency to respond well and easily to people's values and they are adept at assessing the human impact of decisions.

Judging ( $\mathrm{J}$ ) and Perceiving (P) refer to how we "live our outward life". Judging types prefer to live a structured, organized life. They tend to be self-disciplined, they enjoy making decisions, and they thrive on order. Perceiving types prefer to live a more flexible and adaptable lifestyle. They tend to thrive on spontaneity, they prefer to leave things open, require more information in order to make decisions, and often get things done at the last minute (Sprague, 1997). The four dichotomies resulting from completion of Form $M$ are reported as four-letter personality types such as ESTP or ISFJ. Each letter corresponds to an individual's preference in each of the four pairs of personality indicators such as E or I, S or N, T or F, and J or P. There are 16 possible combinations called types.

\subsubsection{Value Stream Mapping and Project performance}

Prior project management researches have identified a wide variety of measures that describe the outcomes of a project and the input characteristics that impact outcomes (Prabhakar, 2008; Thomas \& Fernandez, 2008; Mohanty, Mishra \& Satpathy, 2011). The most commonly used project outcome measures include cost, schedule, technical performance outcomes and 
client satisfaction. The primary challenge of project management is to achieve all of the project goals and objectives while adhering to project constraints (Harrison \& Lock, 2004). Although in general terms project performance is recognized as a multidimensional parameter (Bannerman, 2008) the most cited project output variables are comprised of cost, schedule, technical performance outputs, and customer satisfaction (Meza \& Jeong, 2013). Moreover, most of the project performance evaluation methods used by many organizations do not explicitly consider key input variables that add value for the client (Farris, Groesbeck, Van Aken \& Letens, 2006).

Traditional and new approaches have been proposed in this work for analyzing project performance. Particularly project delay and project over-budget have been used as traditional indexes while waste time and waste type have been proposed as new indexes. Waste time and waste type are often used in lean production management and are assessed using Value Stream Mapping (VSM) techniques. A value stream is defined as all the value-added and nonvalue-added actions required bringing a specific product, service, or combination of products and services, to a customer, including those in the overall supply chain as well as those in internal operations (Rother \& Shook, 1999). The final goal of VSM is to identify all types of waste in the value stream and to find solutions to eliminate those (Jeong \& Phillips, 2011). In this work 40 projects were studied. A panel of experts built up the Value Stream Mapping models of these projects. The panel assumes there is a critical path of activities which lead to the costumer, with the shortest time and lower cost. This path is straightforward: any other practice is longer and more expensive. Comparing resulting value stream with the one obtained during the current project, it was possible to highlight every produced waste. Regarding this, we refer to Christof Bauch's work (2004). He suggests ten categories of waste which are used in this work to analyze managers' type of waste (table 1). A simple project regarding a hydraulic system development is presented in appendix $A$ in order to explain the Value Stream Mapping techniques carried out by a panel of experts for analyzing project wastes. In particular the waste time has been assessed as a difference between real project duration and added value time of the project $(\mathrm{VA} / \mathrm{T})$. VA/T is the project time that provides value to the customer (see the example in figure 2 ). 


\begin{tabular}{|c|c|c|}
\hline Nr. & Type of waste & Description \\
\hline 1) & Waiting & $\begin{array}{l}\text { A) Waiting for capacity available } \\
\text { B) Information is waiting for people } \\
\text { C) Waiting for data, answer, specifications, results, } \\
\text { approvals, decisions, releases, signs }\end{array}$ \\
\hline 2) & Transport/Handoffs & $\begin{array}{l}\text { A) Excessive data traffic } \\
\text { B) Handoffs } \\
\text { C) Stop and go tasks/ Task switching } \\
\text { D) Ineffective communication }\end{array}$ \\
\hline 3) & Movement & $\begin{array}{l}\text { A) Information hunting } \\
\text { B) Remote locations } \\
\text { C) Lack of direct access }\end{array}$ \\
\hline 4) & Over Processing & $\begin{array}{l}\text { A) Unnecessary detail and accuracy } \\
\text { B) Unnecessary features and processes } \\
\text { C) Inappropriate use of competency } \\
\text { D) Use of inappropriate tools/methods } \\
\text { E) Excessive approvals } \\
\text { F) Excessive transactions }\end{array}$ \\
\hline 5) & Inventory & $\begin{array}{l}\text { A) Exceeding capacity utilizations (Queues on critical path) } \\
\text { B) High system variability (Queues on critical path) } \\
\text { C) Large batch sizes (Queues on critical path) } \\
\text { D) Unnecessary testing equipment and prototypes } \\
\text { E) Excessive storage }\end{array}$ \\
\hline 6) & $\begin{array}{l}\text { Overproduction/Un- } \\
\text { synchronized processes }\end{array}$ & $\begin{array}{l}\text { A) Poor synchronization as regards time and capacity } \\
\text { B) Poor synchronization as regards contents } \\
\text { C) Over-dissemination of information } \\
\text { D) Redundant tasks }\end{array}$ \\
\hline 7) & Defects & $\begin{array}{l}\text { A) Deficient information quality } \\
\text { B) Erroneous data and information } \\
\text { C) Poor testing and verification }\end{array}$ \\
\hline 8) & Reinvention & $\begin{array}{l}\text { A) Poor design re-use } \\
\text { B) Poor knowledge re-use }\end{array}$ \\
\hline 9) & Lack of discipline & $\begin{array}{l}\text { A) Unclear goals and objective } \\
\text { B) Unclear roles, responsibilities and rights } \\
\text { C) Unclear rules } \\
\text { D) Insufficient readiness to cooperate } \\
\text { E) Poor schedule discipline } \\
\text { F) Incompetence/Poor training } \\
\end{array}$ \\
\hline 10) & Limited IT Resources & $\begin{array}{l}\text { A) Poor compatibility } \\
\text { B) Poor capability } \\
\text { C) Low capacity }\end{array}$ \\
\hline
\end{tabular}

Table 1. Waste categories (Bauch, 2004)

\subsection{The influence of project managers' personality on project performance}

Numerous researchers, in the past, have investigated the relationship between personality types and professions. Two meta-analyses published in 1991 investigated the relations between Big Five personality dimensions and various aspects of job performance (Barrick \& Mount, 1991; Tett, Jackson \& Rothstein, 1991). Both papers reviewed the existing literature and classified the specific personality measures used in the different studies into one or more of the Big Five factors. The results of the two meta-analyses were similar. Across different occupational groups and measures of job performance, the Big Five markers, particularly conscientiousness, were related to performance.

Some papers have been written analyzing project management personality. The classical definition of a project manager is an Extraverted, Sensing, Thinking, Judging (ESTJ) individual. However, as stated earlier, no one personality fits a given job description or work environment. Shenhar and Wideman (2000) reported on the personality characteristics of project managers. 
Their analysis shows that indeed many MBTI types might be suited for project managers while others are not. However, they confirm that the ESTJ type is a preferred type of project manager. Smith in his research (2001) confirmed Shenhar and Wideman's work (2000) and found the four outer quadrants of the 16 types in the MBTI table as suitable for project management. Mills, Robey and Smith (1985) using the MBTI also found that traditional managers were ESTJ or ISTJ, the $\mathrm{S}$ being the dominant characteristic for project managers. Black and Slaker (2004) found that NT (intuitive thinking) types had greater leadership tendencies. Mullaly and Thomas (2004) compared the general population to career project managers finding them to be INT or IST types. Turner \& Muller (2006) examined the MBTI type as it relates to project management by looking at the interaction of personality type with project type. What can be said of many personality classifications is that one size does not fit all. Dolfi and Andrews (2007) looked at the optimism of project managers and whether optimism, innate or learned, would allow project managers to overcome the impediments associated with the work environment. More recently, Davis (2011) investigated the impact of project managers' emotional intelligence (EI) on their interpersonal competence. Results indicate meaningful relationships with the two models used:

- Assessments based on the ability model (Mayer, Salovey, \& Caruso, 2000) and

- mixed model (Bar-On, 2000) and the domains of conflict management and problem solving.

This study expands research on project managers' characteristics in the area of project management by applying the MBTI to the success of the project. Particular attention has been given to performance indexes that add value for the client.

\subsubsection{Extroverts versus introverts}

Extroversion indicates the preference to engage in and cope with social relationships as well as having a need for social contract (De Jong, Bouhuys \& Barnhoorn, 1999). Extroverts are oriented toward their outer world and focus on people, sociability, and activity. Introverts, by contrast, are oriented primarily toward their inner world. Introverts tend to focus on concepts and ideas and value solitude and privacy (Johnson, Mauzey, Johnson, Murphy \& Zimmerman, 2001). A study of the relationship between personality and job performance found that extroversion was a valid predictor of performance in occupations that require frequent interactions and cooperation (Barrick \& Mount, 1991). Conversely, introverts are typically better suited for tasks requiring few interactions and little interpersonal cooperation. In project management filed networking (internal and external) is essentially about building solid business relationships. To do this a project manager needs good skills in creating rapport and listening. This leads to the following hypotheses: 
- H1: Extroverted project managers carry out projects that show:

- (a) lower delay than introverted project managers.

- (b) lower over-budget than introverted project managers.

- (c) lower waste time than introverted project managers.

- $\mathrm{H} 2$ : There is a relation between the type of waste and the extroverted/introverted personality of project managers.

\subsubsection{Judging versus perception}

In addition to the extrovert-introvert dichotomy, Jungian theory further asserts that an individual has a tendency toward either perceiving or judging as the predominant way in which they deal with their outer world. Perceiving individuals are curious individuals, whose general approach to tasks allows them to be flexible and keep their options open. These attributes allow them to be spontaneous, adaptable, and ready for change. By contrast, people who prefer judging as their way of dealing with the outer world typically approach problem solving in a highly organized and structured manner. The task of managing a project requires managers that follow a structured approach based on project plan, including the project scope, the Work Breakdown Structure (WBS), responsibility assignments, schedules, key staffing requirements, budgets and so on. Moreover, as previously mentioned, all previous studies (Shenhar \& Wideman, 2000; Smith in his research, 2001) showed that judging type is a preferred type of project manager. This leads to propose the following hypotheses:

- H3: Judging project managers carry out projects that show

- (a) lower delay than perceiving project managers.

- (b) lower over-budget than perceiving project managers.

- (c) lower waste time than perceiving project managers.

- $\mathrm{H} 4$ : There is a relation between the type of waste and the judging/perceiving personality of project managers.

\subsubsection{Sensing versus intuition}

The sensing versus intuition dimension reflects a person's preference between two ways of perceiving. An individual may rely on the process of sensing, which involves obtaining facts or 
observing events through one or more of the five senses. Sensing individuals primarily acquire information by relying on their senses, past experiences, and through evaluating objective facts. An individual who relies more on intuition tends to acquire information through imagination or by perceiving objects as possibilities. The studies proposed in literature have different opinions about this aspect. Shenhar and Wideman (2000), Smith (2001) and Mills, Robey and Smith (1985) agree that sensing must be the dominant characteristic for project managers while Black and Slaker (2004) found that intuitive types have greater leadership tendencies. Mullaly and Thomas (2004) say that project managers could have a sensing or intuition dimension. In our opinion, sometimes the project managers need to forecast budget or duration of activities only using their intuitional skills, especially when they have to manage new projects. This leads to propose the following hypotheses:

- H5: Intuitive project managers carry out projects that show:

- (a) lower delay than sensing project managers

- (b) lower over-budget than sensing project managers

- (c) lower waste time than sensing project managers

- H6: There is a relation between the type of waste and the sensing/intuitive personality of project managers.

\subsubsection{Thinking versus feeling}

While individuals exhibit a preference for perceiving or judging, individuals have the ability to use both of these dimensions. For example, an individual who prefers perceiving will still have a primary mode of judging (thinking or feeling). Thus, for completeness, the fourth dimension of personality (thinking versus feeling) is included in the analysis. The thinking versus feeling dimension reflects a person's preference between two ways of decision-making. Thinking individuals make decisions by relying on their cognitive processes and through objective, logical analyses. They are concerned with being critical, objective, just, and fair. Feeling individuals, on the other hand, make decisions by relying on their affective processes and person-centered value judgments. They tend to make decisions based on personal or social values, and focus on the value or merit of an issue. They tend to focus more on subjective rather than objective factors. Good performance in a project requires managers to work logically and cautiously. Thus, those managers who should be better suited to perform projects are those who have a preference for an objective and logical approach to decision making, i.e., are thinking in their orientation. 
This leads to the following hypotheses:

- H7: Thinking project managers carry out projects that show

- (a) lower delay than feeling project managers

- (b) lower over-budget than feeling project managers

- (c) lower waste time than feeling project managers.

- H8: There is a relation between the type of waste and the thinking/feeling personality of project managers.

\section{Research Approach}

Data regarding managers' personality have been obtained by interviews of project managers from different companies that belong to the multinational corporation analyzed in this work. This corporation is made up of 17 companies sited in the main European countries that cover four industrial sectors: mechanical sector (MS), industrial plant design (PD), civil engineering (CE) and design/development of solar and photovoltaic panels (PP). 118 projects of NPD have been carried out by 47 project managers that work in this corporation in 2012. Most of these projects covered a short period (see table 2: mean planned project duration is equal to 91.50 days) and they involved little resources (see table 2: mean number of human resources involved in the projects are equal to 4.35). In order to carry out this research we conducted a census; after we contacted 8 project managers employed in 4 companies of the multinational corporation for the pilot study, 13 companies remained eligible for participation in the main study. The 4 companies used for the pilot study have been chosen in order to cover the four industrial sectors of the multinational corporation. As reported in the previous section this work began by doing literature study, it gave an overview about technical and management practices that can influence the success of a new product development project. In the second step, findings from the literature study helped us to form a questionnaire draft to conduct semi structured interviews with 8 project managers used as a pilot study. Literature review and semi structured interviews allowed us to select:

- the specific technical and management practices of the new products that can influence the success of a new product in the multinational corporation analyzed in this work.

- the best questions that can be used to address these practices.

The respondents in this pilot study had the same type of profile as the respondents in the main study. Based on their assessments and some basic statistical analysis, we modified the wording of some statements to improve clarity; however, no major changes were necessary. 
Than we called the 13 companies involved in the main study and spoke with the CEO, or the project manager to ask for their participation in the study. 11 project managers chose not to take part in the research. 39 projects carried out in 2012 have been discarded because of lack of data or not reliability data. Moreover because of the retrospective nature of this study, several procedures were used to increase the validity of the collected data. The study excluded the following types of projects: those whose development histories were more than 5 years old and those where the key personnel associated with their development had left the organization. Finally 40 projects carried out by 28 different project managers have been considered in the main study. Personal interviews with project managers have been organized in order to:

- explain the objective of this research

- explain the meaning of each question proposed in the questionnaire

- collect information regarding product development project

- fill the questionnaire. Each project manager filled out the questionnaire showed in appendix 2 . It takes approximately 20 minutes to complete.

Few project managers chose not to take part in the research. Finally 40 projects have been considered. Each project manager filled out a copy of the 93-item MBTI form M before beginning the project. It takes approximately 20 to 30 minutes to complete. A panel of experts made up of 6 people has been selected for developing value stream mapping of every project and for analyzing project results. The experts were 2 academics who conduct their research activities in the project management sector and four project managers. An example of the method used for analyzing the forty projects is mentioned in appendix A. In particular, this case study concerns the design of a hydraulic system. For each of the 40 managers, two aspects have been collected:

- their attitudes as measured by the MBTI (see section 3.2), and

- their effectiveness, measured through four parameters (see section 3.1).

Moreover, project manager age, gender and educational level have been registered and used as covariates.

To ensure that the effects of project complexity had been taken into account, three more variables were used as covariates:

- number of human resource involved: that is the team size of the project;

- project sector: four sectors have been taken into consideration in order to cover the 
most important project fields. These sectors are: mechanical sector (MS), industrial plant design (PD), civil engineering (CE) and design and development of solar and photovoltaic panels (PP).

- planned project duration: this is the initial duration of the project assessed by the project manager

\subsection{Dependent variables}

The traditional dependent variables were:

- project delay $=$ planned project duration - real project duration/planned project duration (expressed in percentage terms);

- project over-budget $=$ planned project budget - real project budget/planned project budget (expressed in percentage terms).

The dependent variables based on Value Stream Mapping analysis were:

- $\quad$ waste time $=$ real project duration - value added time of the project (VA/T). VA/T is the project time that provides value to the customer;

- waste types (already mentioned in table 1 ).

\subsection{Independent variables}

The independent variables were each participant's scores on the MBTI test. The scores on the MBTI were used to obtain values for each of the individual's four personality dimensions. These dimensions are extrovert-introvert (EI), sensing-intuition (SN), thinking-feeling (TF), and judging-perceiving (JP). MBTI dimensions were expressed as continuous scores (Bowen, Ferguson, Lehmann \& Rohde, 2003): scores on each of the dimensions on the MBTI range from -40 to 40 . For each dimension, scores below 0 indicate extroverted participants and scores above 0 indicate introverted participants. For example, Figure 1 is a typical profile report from Consulting Psychologists Press, the MBTI authority organization (Choi, Deek \& Im, 2008). In this example, $\mathrm{E}$ is showing a greater presence, on a moderate level, over its counterpart, I. N is showing a greater presence, on a clear level, over its counterpart, S. T is showing a greater presence, on a very clear level, over its counterpart, F. Lastly, J is showing a greater presence, on a moderate level, over its counterpart, P. 


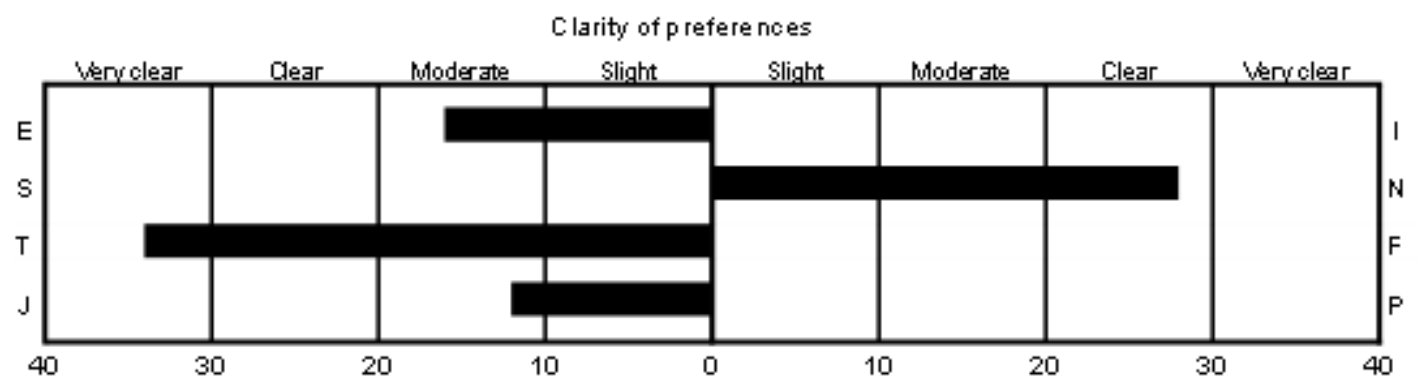

Figure 1. The strengths of MBTI type preferences (Choi, Deek \& Im, 2008)

The score for each dimension was obtained using the combination of the participants reported type and preference scores. In the example the participant's reported type was ENTJ and its resulting preference scores were $16,28,34$, and 12 on each of the dimensions. Then the score for the purposes of this research were:

- 16 on the EI dimension (E being negative and their preference score being -16 ),

- 28 on the SN dimension ( $\mathrm{N}$ being positive and their preference score being 28 ),

- 34 on the TF dimension ( $T$ being negative and their preference score being -34 ), and

- 12 on the JP dimension (J being negative and their preference score being -12 ).

Preference scores are always positive. The type determines the sign of the score.

\section{Results}

In appendix B the data collected is mentioned. Tables 2 and 3 summarize the characteristics of the projects, the managers and their overall performance on the experiment. From table 2, it is possible to highlight the high value of Over-processing type of waste (1.75: mean number of wastes per project). This was essentially due to two causes: "use of inappropriate tools/methods" and "excessive approvals". Table 3 shows that the 16 MBTI personality types are disproportionately distributed. Some types are not present (i.e. ENFJ, ENFP, ...), some types are preferred by just $7 \%$ of the population (i.e., ENTJ, ENTP, ...), whereas three are preferred by as much as $15 \%$ of the population (i.e., ESFJ, ESFP, ISTP). The most prevalent MBTI types are ESFP (17.5\%). As a result, the analysis has been completed with respect to each of the four personality preference scales rather than full types: $E$ versus $I, S$ versus $N, T$ versus $F$, and $J$ versus $P$. The distribution of individuals into personality dimensions is relatively symmetrical, except on the Sensing (S) - Intuitive (N) dimension where the number of Sensing individuals is $30(75 \%)$ and the number of Intuitive individuals only $10(25 \%)$. With respect to the four separate MBTI dimensions scales, managers tend to prefer E over I, S over $\mathrm{N}, \mathrm{T}$ over $\mathrm{F}$ and $\mathrm{P}$ over $\mathrm{J}$. 


\begin{tabular}{|l|l|}
\hline \multicolumn{1}{|c|}{ Attribute or out come } & \multicolumn{1}{|c|}{ Summary } \\
\hline Age of project managers: mean (SD) & $46.78(6.70)$ \\
\hline Gender of project managers & 25 \\
\hline - Number of males & 15 \\
\hline - Number of females & \\
\hline Educational level of project managers & 9 \\
\hline - Diploma or below & 11 \\
\hline - Bachelor & 16 \\
\hline - Master & 4 \\
\hline - PhD & $4.35(1.08)$ \\
\hline $\begin{array}{l}\text { Number of human resources involved in the projects: mean number per } \\
\text { project (SD) }\end{array}$ & \\
\hline Planned project duration (days): mean (SD) & $91.50(19.78)$ \\
\hline Number of projects per sector & \\
\hline - Mechanical sector (MS) & 8 \\
\hline - Industrial plant design (PD) & 10 \\
\hline - Civil engineering (CE) & 14 \\
\hline - Solar and photovoltaic panels (PP) & 8 \\
\hline$\%$ Delay: mean (SD) & $25.4 \%(14.7 \%)$ \\
\hline$\%$ Over-budget: mean (SD) & $26.5 \%(15.2 \%)$ \\
\hline Waste time (days): mean (SD) & $52.10(26.36)$ \\
\hline Type of waste & \\
\hline - Waiting: mean number per project (SD) & $0.98(0.70)$ \\
\hline - Transport/ handoffs: mean number per project (SD) & $0.60(0.81)$ \\
\hline - Movement: mean number per project (SD) & $1.00(0.93)$ \\
\hline - Over processing: mean number per project (SD) & $1.75(1.19)$ \\
\hline - Inventory: mean number per project (SD) & $0.30(0.52)$ \\
\hline - Overproduction/un-synchronized processing: mean number per project (SD) & $0.30(0.46)$ \\
\hline - Defects: mean number per project (SD) & $0.28(0.45)$ \\
\hline - Reinvention: mean number per project (SD) & $0.25(0.49)$ \\
\hline - Lack of discipline: mean number per project (SD) & $0.23(0.42)$ \\
\hline - Limited IT resources: mean number per project (SD) & $0.28(0.45)$ \\
\hline
\end{tabular}

Table 2. Project characteristics and summary performance

\begin{tabular}{|c|c|c|c|c|c|}
\hline Personality type & $\mathbf{N}$ & Personality type & $\mathbf{n}$ & MTBI dimensions & N \\
\hline ENFJ & 0 & INFJ & 0 & Extroverted (E) & 26 \\
\hline ENFP & 0 & INTJ & 2 & Introverted (I) & 14 \\
\hline ENTJ & 3 & INTP & 2 & Sensing (S) & 30 \\
\hline ENTP & 3 & INFP & 0 & Intuitive (N) & 10 \\
\hline ESFJ & 6 & ISFJ & 4 & Thinking (T) & 23 \\
\hline ESFP & 7 & ISFP & 0 & Feeling (F) & 17 \\
\hline ESTJ & 4 & ISTJ & 0 & Judging (J) & 19 \\
\hline ESTP & 3 & ISTP & 6 & Perceiving (P) & 21 \\
\hline
\end{tabular}

Table 3. Personality types of project managers

\subsection{The effect of personality measures on project performance}

Table 4 presents the Pearson correlations among the traditional dependent variables ( $\%$ of delay and \% of over-budget), the independent variables (scores on the MBTI dimensions) and the covariates (gender, age, educational level, company sector, human resources involved and planned project duration). Table 5 presents the Pearson correlations among the independent variables, the covariates and the dependent variables based on Value Stream Mapping (waste time and type of waste). 


\begin{tabular}{|c|c|c|c|c|c|c|c|c|c|c|c|}
\hline & Delay & $\begin{array}{l}\text { Over- } \\
\text { Budget }\end{array}$ & 1 & 2 & 3 & 4 & 5 & 6 & 7 & 8 & 9 \\
\hline Gender & .171 & .162 & & & & & & & & & \\
\hline Age & -.075 & .000 & -.044 & & & & & & & & \\
\hline Educational_level ${ }^{a}$ & .121 & .030 & -.034 & -.111 & & & & & & & \\
\hline Company_sector ${ }^{\mathbf{b}}$ & .213 & .226 & -.013 & -.203 & .097 & & & & & & \\
\hline Human_resources & .260 & -.166 & -.158 & .274 & -.056 & .145 & & & & & \\
\hline Planned_duration & $.327^{*}$ & .158 & -.073 & .250 & .092 & $.396 *$ & $.523 * *$ & & & & \\
\hline$E^{c}$ & $.349 *$ & .046 & .025 & .113 & .002 & .090 & -.019 & -.016 & & & \\
\hline $\mathbf{S N}^{\mathrm{c}}$ & .103 & $.339 *$ & .155 & $.347^{*}$ & -.100 & .110 & -.120 & .025 & .141 & & \\
\hline TF $^{\mathrm{c}}$ & .017 & -.047 & -.025 & -.295 & .021 & -.160 & -.076 & -.084 & -.209 & $-.422 * *$ & \\
\hline$J^{\mathrm{c}}$ & $-.361 *$ & $-.508^{* *}$ & .002 & -.098 & -.028 & -.035 & .163 & -.186 & -.058 & $-.318^{*}$ & -.091 \\
\hline
\end{tabular}

${ }^{a}$ Educational level was coded as Diploma or below $=1$; Bachelor $=2 ;$ Master $=3 ; \mathrm{PhD}=4$.

${ }^{b}$ Company sector was coded as $1=P P ; 2=M S ; 3=P D ;$ and $4=C E$.

${ }^{c}$ Positive scores are indicated by the dimensions $\mathrm{I}, \mathrm{N}, \mathrm{F}$, and $\mathrm{P}$ and negative scores by the dimensions $\mathrm{E}, \mathrm{S}, \mathrm{T}$ and $\mathrm{J}$.

$* \mathrm{p}<0.05$

$* * \mathrm{p}<0.01$.

Table 4. Correlations between variables and traditional performance indexes

\begin{tabular}{|l|c|c|c|c|c|c|}
\cline { 2 - 6 } \multicolumn{1}{c|}{} & $\begin{array}{c}\text { Waste } \\
\text { time }\end{array}$ & Waiting & $\begin{array}{c}\text { Transport } \\
\text { handoffs }\end{array}$ & Movement & $\begin{array}{c}\text { Over } \\
\text { processing }\end{array}$ & Inventory \\
\hline gender & -.001 & .028 & .258 & -.112 & .077 & .253 \\
\hline age & .024 & -.166 & .106 & -.209 & -.107 & -.128 \\
\hline Educational level & .218 & .092 & .000 & .173 & .197 & .078 \\
\hline Company sector $^{\mathrm{b}}$ & $.427 * *$ & .020 & -.006 & $.477 * *$ & .259 & .019 \\
\hline Human resources & $.426 * *$ & -.022 & .165 & .179 & -.010 & .083 \\
\hline Planned duration & $.621 * *$ & -.164 & .070 & .194 & .261 & .156 \\
\hline EI $^{c}$ & $.333^{c}$ & .293 & .123 & $.318 *$ & $.349 *$ & .114 \\
\hline SN $^{c}$ & .136 & .000 & .059 & .195 & .265 & .051 \\
\hline TF $^{c}$ & -.132 & .134 & -.001 & $-.379 *$ & -.224 & .048 \\
\hline JP $^{c}$ & -.219 & -.124 & -.004 & -.124 & $-.359 *$ & -.214 \\
\hline
\end{tabular}

${ }^{\mathrm{a}}$ Educational level was coded as Diploma or below $=1 ;$ Bachelor $=2 ;$ Master $=3 ; \mathrm{PhD}=4$.

${ }^{\mathrm{b}}$ Company sector was coded as $1=\mathrm{PP} ; 2=\mathrm{MS} ; 3=\mathrm{PD}$; and $4=\mathrm{CE}$.

c Positive scores are indicated by the dimensions I, N, F, and P and negative scores by the dimensions $\mathrm{E}, \mathrm{S}, \mathrm{T}$ and $\mathrm{J}$.

$* \mathrm{p}<0.05$.

$* * \mathrm{p}<0.01$.

\begin{tabular}{|c|c|c|c|c|c|}
\hline & $\begin{array}{c}\text { Over } \\
\text { production }\end{array}$ & Defects & Reinvention & $\begin{array}{c}\text { Lack } \\
\text { discipline }\end{array}$ & $\begin{array}{l}\text { Limited IT } \\
\text { resources }\end{array}$ \\
\hline gender & .056 & .101 & -.079 & -.046 & -.014 \\
\hline age & -.151 & .038 & -.107 & -.108 & -.081 \\
\hline Educational level ${ }^{\mathrm{a}}$ & .087 & -.067 & .177 & -.088 & .112 \\
\hline Company sector ${ }^{b}$ & -.192 & $.325^{*}$ & .276 & -.056 & .052 \\
\hline Human resources & .144 & -.098 & -.024 & .104 & .219 \\
\hline Planned duration & .089 & .024 & .276 & .035 & .196 \\
\hline$E I^{c}$ & -.063 & $.417 * *$ & .122 & -.213 & .073 \\
\hline$S N^{c}$ & -.255 & .251 & .062 & -.071 & -.122 \\
\hline $\mathrm{TF}^{\mathrm{c}}$ & .260 & -.129 & .064 & -.086 & -.119 \\
\hline$J^{c}$ & -.074 & -.107 & -.022 & -.021 & .135 \\
\hline
\end{tabular}

a Educational level was coded as Diploma or below $=1$; Bachelor $=2 ;$ Master $=3 ; \mathrm{PhD}=4$.

${ }^{\mathrm{b}}$ Company sector was coded as $1=\mathrm{PP} ; 2=\mathrm{MS} ; 3=\mathrm{PD}$; and $4=\mathrm{CE}$.

c Positive scores are indicated by the dimensions I, N, F, and P and negative scores by the dimensions

E, S, T and J.

$* \mathrm{p}<0.05$.

$* * \mathrm{p}<0.01$.

Table 5. Correlations between variables and performance indexes based on VSM 
Remembering that each individual exhibited two different traits that were related to attitudes, each individual has a social orientation attitude (extroverted or introverted) and a second attitude known as judging or perceiving. The judging-perceiving attitude is a person's attitude toward the interaction of their sensing-intuition trait and their thinking-feeling trait. These two attitude traits are tested in one model to determine whether particular attitude traits may affect performance. Tables 6 and 7 contain the results of the effects of the manager's social orientation (extrovert-introvert) and the manner in which they deal with the outer world (perceiving or judging) on traditional and VSM performance indexes. A Hierarchical Multiple Regression has been developed for verifying cause and effect relations. We entered the covariates in step 1, and independent variables in step 2 and 3 . In the table, entries represent standardized coefficient.

\begin{tabular}{|c|c|c|}
\hline Predictor variable & $\%$ Delay & Over-Budget \\
\hline \multicolumn{3}{|c|}{ Step 1} \\
\hline Gender & .218 & .134 \\
\hline Age & -.166 & .071 \\
\hline Educationallevel $^{\mathrm{a}}$ & .094 & -.017 \\
\hline Companysector $^{\mathrm{b}}$ & .044 & .195 \\
\hline Human_resources & .209 & -.320 \\
\hline Planned_duration & .249 & .241 \\
\hline \multicolumn{3}{|c|}{ Step 2} \\
\hline $\mathrm{EI}^{\mathrm{c}}$ & $.382 *$ & .015 \\
\hline Change in $\mathrm{R}^{2}$ & $.140 *$ & .001 \\
\hline Change in $\mathrm{F}$ & $6.851 *$ & .009 \\
\hline \multicolumn{3}{|c|}{ Step 3} \\
\hline$J P^{c}$ & $-.400 * *$ & $-.464 *$ \\
\hline Change in $\mathrm{R}^{2}$ & $.137 * *$ & $0.184^{*}$ \\
\hline Change in $\mathrm{F}$ & $8.188^{* * *}$ & $8.658^{*}$ \\
\hline \multicolumn{3}{|c|}{$\begin{array}{l}\text { aducational level was coded as Diploma or below }=1 ; \text { Bachelor }=2 ; \\
\text { Master }=3 ; \mathrm{PhD}=4 . \\
\text { b Company sector was coded as } 1=\mathrm{PP} ; 2=\mathrm{MS} ; 3=\mathrm{PD} ; \text { and } 4=\mathrm{CE} \text {. } \\
\text { c Positive scores are indicated by the dimensions I and P and negative } \\
\text { scores by the dimensions } \mathrm{E} \text { and } \mathrm{J} \text {. } \\
* \mathrm{p}<0.05 . \\
* * \mathrm{p}<0.01 . \\
* * * \mathrm{p}<0.005\end{array}$} \\
\hline
\end{tabular}

Table 6. Effect of EI and JP on traditional performance indexes

\begin{tabular}{|c|c|c|c|c|c|c|}
\hline Predictor variable & $\begin{array}{c}\text { Waste } \\
\text { time }\end{array}$ & Waiting & $\begin{array}{l}\text { Transport } \\
\text { handoffs }\end{array}$ & Movement & $\begin{array}{c}\text { Over } \\
\text { processing }\end{array}$ & Inventory \\
\hline \multicolumn{7}{|c|}{ Step 1} \\
\hline Gender & .069 & .032 & .294 & -.084 & .079 & .275 \\
\hline Age & -.086 & -.119 & .072 & -.148 & -.099 & -.218 \\
\hline Educational level ${ }^{\mathrm{a}}$ & .163 & .103 & .034 & .126 & .142 & .060 \\
\hline Company sectorb & .186 & .060 & -.007 & $.427 *$ & .128 & -.132 \\
\hline Human resources & .207 & .137 & .215 & .176 & -.138 & .088 \\
\hline Planned duration & $.450^{*}$ & -.237 & -.039 & -.048 & .300 & .231 \\
\hline \multicolumn{7}{|c|}{ Step 2} \\
\hline$E I^{c}$ & $.350 *$ & .311 & .116 & $.313^{*}$ & $.363 *$ & .155 \\
\hline Change in $R^{2}$ & $.117^{*}$ & .093 & .013 & $.094 *$ & $.127 *$ & .023 \\
\hline Change in F & $9.334^{*}$ & 3.546 & .475 & $4.886^{*}$ & $5.652 *$ & .884 \\
\hline \multicolumn{7}{|c|}{ Step 3} \\
\hline$J^{c}$ & -.174 & -.212 & -.038 & -.166 & -.309 & -.237 \\
\hline Change in $R^{2}$ & .026 & .038 & .001 & .024 & .081 & .048 \\
\hline Change in F & 2.142 & 1.482 & .045 & 1.227 & 3.978 & 1.889 \\
\hline
\end{tabular}




\begin{tabular}{|c|c|c|c|c|c|}
\hline $\begin{array}{l}\text { Predictor } \\
\text { variable }\end{array}$ & $\begin{array}{c}\text { Over } \\
\text { production }\end{array}$ & Defects & Reinvention & $\begin{array}{c}\text { Lack } \\
\text { discipline }\end{array}$ & $\begin{array}{l}\text { Limited IT } \\
\text { resources }\end{array}$ \\
\hline \multicolumn{6}{|c|}{ Step 1} \\
\hline Gender & .086 & .081 & -.086 & -.034 & .024 \\
\hline Age & -.322 & .187 & -.098 & -.204 & -.184 \\
\hline $\begin{array}{l}\text { Educational } \\
\text { level }^{\mathrm{a}}\end{array}$ & .082 & -.085 & .108 & -.098 & .097 \\
\hline $\begin{array}{l}\text { Company } \\
\text { sector }^{\mathrm{b}}\end{array}$ & $-.379 *$ & $.435^{*}$ & 141 & -.138 & -.089 \\
\hline $\begin{array}{l}\text { Human } \\
\text { resources }\end{array}$ & 191 & -.150 & -.199 & .127 & 207 \\
\hline $\begin{array}{l}\text { Planned } \\
\text { duration }\end{array}$ & 219 & -.103 & $.332 *$ & .081 & .162 \\
\hline \multicolumn{6}{|c|}{ Step 2} \\
\hline$E^{c}$ & .013 & $.365^{*}$ & .129 & -.180 & .112 \\
\hline Change in $R^{2}$ & .001 & $128^{*}$ & .016 & .031 & .012 \\
\hline Change in $F$ & .006 & $5.881 *$ & .627 & 1.084 & .431 \\
\hline \multicolumn{6}{|c|}{ Step 3} \\
\hline$J^{c}$ & -.124 & -.061 & .090 & -.074 & .138 \\
\hline Change in $\mathbf{R}^{2}$ & .013 & .003 & .007 & .005 & .016 \\
\hline Change in $F$ & .506 & .142 & .268 & 159 & .582 \\
\hline
\end{tabular}

a Educational level was coded as Diploma or below $=1$; Bachelor $=2$; Master $=3 ; \mathrm{PhD}=4$.

${ }^{b}$ Company sector was coded as $1=P P ; 2=M S ; 3=P D ;$ and $4=C E$.

${ }^{c}$ Positive scores are indicated by the dimensions $\mathrm{I}$ and $\mathrm{P}$ and negative scores by the dimensions $\mathrm{E}$ and $\mathrm{J}$.

$* p<0.05$.

Table 7. Effect of EI and JP on VSM performance indexes

Each person also exhibited two mental functions (Wheeler, 2001). The two ways in which individuals use these two mental functions offer an explanation as to why people perceive the world differently and why people form judgments differently. Individuals prefer one way of perceiving (sensing or intuition) and have one primary way of judging (thinking or feeling). These two mental function traits are tested to determine whether the mental function traits affect performance. Tables 8 and 9 contain the results for traditional and VSM performance indexes by the individual's preferred method of perceiving (sensing-intuition) and by their preferred manner for judging (thinking-feeling).

\begin{tabular}{|c|c|c|}
\hline Predictor variable & $\%$ Delay & Over-Budget \\
\hline \multicolumn{3}{|c|}{ Step 1} \\
\hline Gender & .218 & .134 \\
\hline Age & -.166 & .071 \\
\hline Educational_level ${ }^{\mathrm{a}}$ & .094 & -.017 \\
\hline Company_sector ${ }^{\mathrm{b}}$ & .044 & .195 \\
\hline Human_resources & .209 & -.320 \\
\hline Planned_duration & .249 & .241 \\
\hline \multicolumn{3}{|c|}{ Step 2} \\
\hline $\mathbf{S N}^{\mathrm{c}}$ & .202 & .303 \\
\hline Change in $\mathbf{R}^{2}$ & .030 & .069 \\
\hline Change in $\mathbf{F}$ & 1.274 & 2.832 \\
\hline \multicolumn{3}{|c|}{ Step 3} \\
\hline TF & .087 & .107 \\
\hline Change in $\mathbf{R}^{2}$ & .006 & .009 \\
\hline Change in $\mathrm{F}$ & .238 & .354 \\
\hline
\end{tabular}

${ }^{a}$ Educational level was coded as Diploma or below $=1$; Bachelor $=2$; Master $=3 ; \mathrm{PhD}=4$.

${ }^{\mathrm{b}}$ Company sector was coded as $1=P P ; 2=M S ; 3=P D ;$ and $4=C E$.

c Positive scores are indicated by the dimensions $\mathrm{N}$ and $\mathrm{F}$ and

negative scores by the dimensions $\mathrm{S}$ and $\mathrm{T}$.

$* \mathrm{p}<0.05$.

$* * \mathrm{p}<0.01$.

$* * * \mathrm{p}<0.005$

Table 8. Effect of SN and TF on traditional performance indexes 


\begin{tabular}{|c|c|c|c|c|c|c|}
\hline $\begin{array}{l}\text { Predictor } \\
\text { variable }\end{array}$ & $\begin{array}{l}\text { Waste } \\
\text { time }\end{array}$ & Waiting & $\begin{array}{l}\text { Transport } \\
\text { handoffs }\end{array}$ & Movement & $\begin{array}{c}\text { Over } \\
\text { processing }\end{array}$ & Inventory \\
\hline \multicolumn{7}{|c|}{ Step 1} \\
\hline Gender & .069 & .032 & .294 & -.084 & .079 & .275 \\
\hline Age & -.086 & -.119 & .072 & -.148 & -.099 & -.218 \\
\hline $\begin{array}{l}\text { Educational } \\
\text { level }^{\mathrm{a}}\end{array}$ & .163 & .103 & .034 & .126 & .142 & .060 \\
\hline $\begin{array}{l}\text { Company } \\
\text { sector }^{\mathrm{b}}\end{array}$ & .186 & .060 & -.007 & $.427 *$ & .128 & -.132 \\
\hline $\begin{array}{l}\text { Human } \\
\text { resources }\end{array}$ & 207 & .137 & .215 & .176 & -.138 & .088 \\
\hline $\begin{array}{l}\text { Planned } \\
\text { duration }\end{array}$ & $.450 * *$ & -.237 & -.039 & -.048 & .300 & .231 \\
\hline \multicolumn{7}{|c|}{ Step 2} \\
\hline SN $^{c}$ & .221 & .083 & .026 & $.332 *$ & .652 & .146 \\
\hline Change in $\mathbf{R}^{2}$ & .036 & .005 & .001 & $.082 *$ & .093 & .016 \\
\hline Change in F & 2.411 & .178 & .018 & $4.179 *$ & 3.946 & .606 \\
\hline \multicolumn{7}{|c|}{ Step 3} \\
\hline $\mathrm{TF}^{\mathrm{c}}$ & -.026 & .155 & .059 & $-.348^{*}$ & -.170 & .041 \\
\hline Change in $R^{2}$ & .001 & .018 & .003 & $.092 *$ & .022 & .001 \\
\hline Change in $\mathrm{F}$ & .033 & .627 & .093 & 5.327* & .938 & .046 \\
\hline
\end{tabular}

${ }^{a}$ Educational level was coded as Diploma or below $=1$; Bachelor $=2 ;$ Master $=3 ; \mathrm{PhD}=4$.

${ }^{b}$ Company sector was coded as $1=P P ; 2=M S ; 3=P D ;$ and $4=C E$.

${ }^{\mathrm{c}}$ Positive scores are indicated by the dimensions $\mathrm{N}$ and $\mathrm{F}$, and negative scores by the dimensions $\mathrm{S}$ and $\mathrm{T}$.

$* \mathrm{p}<0.05$.

$* * \mathrm{p}<0.01$.

\begin{tabular}{|c|c|c|c|c|c|}
\hline $\begin{array}{l}\text { Predictor } \\
\text { variable }\end{array}$ & $\begin{array}{c}\text { Over } \\
\text { production }\end{array}$ & Defects & Reinvention & $\begin{array}{c}\text { Lack } \\
\text { discipline }\end{array}$ & $\begin{array}{l}\text { Limited IT } \\
\text { resources }\end{array}$ \\
\hline \multicolumn{6}{|c|}{ Step 1} \\
\hline Gender & .086 & .081 & -.086 & -.034 & .024 \\
\hline Age & $-.322 *$ & .187 & -.098 & -.204 & -.184 \\
\hline $\begin{array}{l}\text { Educational } \\
\text { level }^{\mathrm{a}}\end{array}$ & .082 & -.085 & .108 & -.098 & .097 \\
\hline $\begin{array}{l}\text { Company } \\
\text { sector }^{b}\end{array}$ & $-.379 *$ & $.435^{*}$ & .141 & -.138 & -.089 \\
\hline $\begin{array}{l}\text { Human } \\
\text { resources }\end{array}$ & .191 & -.150 & -.199 & .127 & .207 \\
\hline $\begin{array}{l}\text { Planned } \\
\text { duration }\end{array}$ & .219 & -.103 & .332 & .081 & .162 \\
\hline \multicolumn{6}{|c|}{ Step 2} \\
\hline$S N^{c}$ & -.121 & .137 & .097 & .032 & -.030 \\
\hline $\begin{array}{l}\text { Change in } \\
\mathbf{R}^{2}\end{array}$ & .011 & .014 & .007 & .001 & .001 \\
\hline Change in F & .429 & .553 & .271 & .026 & .023 \\
\hline \multicolumn{6}{|c|}{ Step 3} \\
\hline TF $^{c}$ & .141 & .019 & .119 & -.187 & -.220 \\
\hline $\begin{array}{l}\text { Change in } \\
\mathbf{R}^{2}\end{array}$ & .015 & .001 & .011 & .027 & .037 \\
\hline Change in $F$ & .591 & .010 & .414 & .899 & 1.319 \\
\hline
\end{tabular}

${ }^{a}$ Educational level was coded as Diploma or below $=1$; Bachelor $=2$; Master $=3 ; \mathrm{PhD}=4$.

${ }^{b}$ Company sector was coded as $1=\mathrm{PP} ; 2=\mathrm{MS} ; 3=\mathrm{PD}$; and $4=\mathrm{CE}$.

c Positive scores are indicated by the dimensions $\mathrm{N}$ and $\mathrm{F}$, and negative scores by the dimensions $\mathrm{S}$ and $\mathrm{T}$.

$* \mathrm{p}<0.05$.

$* * \mathrm{p}<0.01$.

Table 9. Effect of SN and TF on VSM performance indexes

Each individual's personality consists of all eight traits (four pairs) and one trait from each of the four pairs is preferred. The four preferred traits interact to define the personality. Taking this into account, a third model was tested. This model contains the two attitudes and the two mental functions, i.e., the four personality dimensions. Tables 10 and 11 contain the effects of 
the individual's social orientation (extrovert-introvert), the manner in which they deal with the outer world (perceiving or judging), the individual's preferred method of perceiving (sensingintuition), and their preferred manner for judging (thinking-feeling) on traditional and VSM performance indexes. In each of the two regressions, gender, age, educational level, company sector, human resources involved and planned duration were included as covariates.

\begin{tabular}{|c|c|c|}
\hline Predictor variable & $\%$ Delay & Over-Budget \\
\hline \multicolumn{3}{|c|}{ Step 1} \\
\hline Gender & .214 & .125 \\
\hline Age & -.290 & -.051 \\
\hline Educational level ${ }^{a}$ & .100 & .003 \\
\hline Company sector ${ }^{b}$ & -.014 & .165 \\
\hline Human resources & $.383 *$ & -.116 \\
\hline Planned duration & .150 & .092 \\
\hline \multicolumn{3}{|c|}{ Step 2} \\
\hline$E^{c}$ & $.365 *$ & -.016 \\
\hline SN $^{\mathrm{c}}$ & .075 & .172 \\
\hline$T^{c}$ & .048 & -.003 \\
\hline$J^{c}$ & $-.372 *$ & $-.418^{*}$ \\
\hline Overall $F$ for the equation & $2.748^{*}$ & 1.639 \\
\hline Overall $\mathbf{R}^{2}$ & $.487 *$ & .361 \\
\hline \multicolumn{3}{|c|}{$\begin{array}{l}\text { a Educational level was coded as Diploma or below }=1 ; \text { Bachelor }= \\
2 ; \text { Master }=3 ; \mathrm{PhD}=4 \text {. } \\
{ }^{\mathrm{b}} \text { Company sector was coded as } 1=\mathrm{PP} ; 2=\mathrm{MS} ; 3=\mathrm{PD} ; \text { and } 4=\mathrm{CE} \text {. } \\
{ }^{\mathrm{C}} \text { Positive scores are indicated by the dimensions I, N, F, and P and } \\
\text { negative scores by the dimensions } \mathrm{E}, \mathrm{S}, \mathrm{T} \text { and } \mathrm{J} \text {. } \\
* \mathrm{p}<0.05 \text {. }\end{array}$} \\
\hline
\end{tabular}

Table 10. Effect of EI, SN, TF and JP on traditional performance indexes

\begin{tabular}{|c|c|c|c|c|c|}
\hline $\begin{array}{l}\text { Predictor } \\
\text { variable }\end{array}$ & Waste time & Waiting & $\begin{array}{c}\text { Transport_h } \\
\text { andoffs }\end{array}$ & Movement & $\begin{array}{l}\text { Over_proce } \\
\text { ssing }\end{array}$ \\
\hline \multicolumn{6}{|c|}{ Step 1} \\
\hline Gender & .045 & .028 & .289 & -.115 & .051 \\
\hline Age & -.240 & -.164 & .057 & $-.416 *$ & $-.345^{*}$ \\
\hline $\begin{array}{l}\text { Educational } \\
\text { level }^{\mathrm{a}}\end{array}$ & .171 & .106 & .036 & .133 & .153 \\
\hline $\begin{array}{l}\text { Company } \\
\text { sector }^{b}\end{array}$ & .087 & .039 & -.017 & .250 & -.021 \\
\hline $\begin{array}{l}\text { Human } \\
\text { resources }\end{array}$ & $.306 *$ & .228 & .234 & .287 & .026 \\
\hline $\begin{array}{l}\text { Planned } \\
\text { duration }\end{array}$ & $.449 *$ & -.281 & -.038 & -.034 & .261 \\
\hline \multicolumn{6}{|c|}{ Step 2} \\
\hline$E I^{c}$ & $.333^{*}$ & .322 & .123 & .246 & $.311^{*}$ \\
\hline $\mathrm{SN}^{\mathrm{c}}$ & .152 & .061 & .036 & .136 & .171 \\
\hline $\mathrm{TF}^{\mathrm{c}}$ & -.009 & .161 & .073 & $-.356 *$ & -.196 \\
\hline $\mathrm{JP}^{\mathrm{c}}$ & -.134 & -.172 & -.018 & -.180 & -.290 \\
\hline $\begin{array}{l}\text { Overall F } \\
\text { for the } \\
\text { equation }\end{array}$ & $5.158 * * *$ & .802 & .449 & $3.526 * * *$ & $2.236 *$ \\
\hline Overall $\mathbf{R}^{2}$ & $.640 * * *$ & .217 & .134 & $.549 * *$ & $.435 *$ \\
\hline \multicolumn{6}{|c|}{$\begin{array}{l}\text { a Educational level was coded as Diploma or below }=1 ; \text { Bachelor }=2 ; \text { Master }=3 ; \mathrm{PhD}=4 . \\
\text { b Company sector was coded as } 1=\mathrm{PP} ; 2=\mathrm{MS} ; 3=\mathrm{PD} ; \text { and } 4=\mathrm{CE} \text {. } \\
\text { c Positive scores are indicated by the dimensions I, N, F, and P and negative scores by the } \\
\text { dimensions } \mathrm{E}, \mathrm{S}, \mathrm{T} \text { and } \mathrm{J} \text {. } \\
* \mathrm{p}<0.05 . \\
* * \mathrm{p}<0.01 \text {. } \\
* * * \mathrm{p}<0.005\end{array}$} \\
\hline
\end{tabular}




\begin{tabular}{|c|c|c|c|c|c|}
\hline $\begin{array}{l}\text { Predictor } \\
\text { variable }\end{array}$ & Inventory & $\begin{array}{c}\text { Over } \\
\text { production }\end{array}$ & Defects & Reinvention & $\begin{array}{c}\text { Lack } \\
\text { discipline }\end{array}$ \\
\hline \multicolumn{6}{|c|}{ Step 1} \\
\hline Gender & .269 & .112 & .058 & -.115 & -.024 \\
\hline Age & -.297 & -.236 & .081 & -.136 & -.235 \\
\hline $\begin{array}{l}\text { Educational } \\
\text { levela }^{\text {a }}\end{array}$ & .066 & .074 & -.080 & .120 & -.101 \\
\hline $\begin{array}{l}\text { Company } \\
\text { sector }^{b}\end{array}$ & -.166 & -.311 & $.355^{*}$ & .105 & -.146 \\
\hline $\begin{array}{l}\text { Human } \\
\text { resources }\end{array}$ & .194 & .216 & -.101 & -.211 & .152 \\
\hline $\begin{array}{l}\text { Planned } \\
\text { duration }\end{array}$ & .169 & .146 & -.066 & $.404^{*}$ & .033 \\
\hline \multicolumn{6}{|c|}{ Step 2} \\
\hline$E I^{c}$ & .141 & .028 & $.368^{*}$ & .153 & -.218 \\
\hline SN $^{c}$ & .070 & -.131 & .130 & .204 & -.081 \\
\hline$T^{c}$ & .007 & .108 & .072 & .187 & -.254 \\
\hline $\mathrm{JP}^{\mathrm{c}}$ & -.217 & -.144 & -.015 & .172 & -.132 \\
\hline $\begin{array}{l}\text { Overall F } \\
\text { for the } \\
\text { equation }\end{array}$ & .804 & .831 & 1.343 & .866 & .461 \\
\hline Overall $\mathbf{R}^{2}$ & .217 & .223 & .317 & .230 & .137 \\
\hline \multicolumn{6}{|c|}{$\begin{array}{l}\text { a Educational level was coded as Diploma or below }=1 ; \text { Bachelor }=2 ; \text { Master }=3 ; \text { PhD }=4 \text {. } \\
\text { b Company sector was coded as } 1=\mathrm{PP} ; 2=\mathrm{MS} ; 3=\mathrm{PD} ; \text { and } 4=\mathrm{CE} \text {. } \\
{ }^{\mathrm{c}} \text { Positive scores are indicated by the dimensions } \mathrm{I}, \mathrm{N}, \mathrm{F} \text {, and } \mathrm{P} \text { and negative scores by the } \\
\text { dimensions } \mathrm{E}, \mathrm{S}, \mathrm{T} \text { and } \mathrm{J} \text {. } \\
* \mathrm{p}<0.05 \text {. } \\
\text { ** } \mathrm{p}<0.01 \text {. } \\
* * * \mathrm{p}<0.005\end{array}$} \\
\hline
\end{tabular}

Table 11. Effect of EI, SN, TF and JP on VSM performance indexes

\subsubsection{The effect of the extroverted-introverted dimension on project performance}

$\mathrm{H} 1$ stated that extroverted project managers exhibit higher project performance, in terms of (a) \% delay, (b) over-budget and (c) waste time, than introverted project managers.

Correlations in Table 4 indicating that managers' EI is correlated positively (Pearson's correlation coefficient $=.349, \mathrm{p}<0.05$, two tailed test) with project delay provide initial support for Hypothesis 1 (a). Similarly, EI is significant in the regression ( $\Delta \mathrm{R} 2=.140$ and $\Delta \mathrm{F}=$ $6.851, \mathrm{p}<0.05$, two-tailed test: table 6$)$. When the attitudes are combined with the remaining personality traits, the conclusions are similar $(B=.365, p<0.05$, two-tailed test: table 10$)$. Regarding relationships between performance (in terms of \% delay) and personalities, the results obtained show that extroverted managers have a significantly lower delay in comparison with introverted ones. Thus, $\mathrm{H} 1(\mathrm{a})$ is supported.

The correlation between over-budget and EI was not significant (table 4). Similarly, EI is not significant in either of the two regressions (tables 6 and 10). Thus, H1(b) is not supported.

The correlation between Waste time and EI was significant (Pearson's correlation coefficient $=$. 333, $\mathrm{p}<0.05$, two-tailed test: Table 5$)$. Similarly, $\mathrm{EI}$ is significant in either regression $(\Delta \mathrm{R} 2=$. 117 and $\Delta \mathrm{F}=9.334, \mathrm{p}<0.05$, two-tailed test: table 7$)(\mathrm{B}=.333, \mathrm{p}<0.05$, two-tailed test: table 11). 
H2 stated that there is a relation between type of waste and extroverted/introverted personality of project managers. The "Over-Processing" type of wastes are done significantly more by Introverted than Extroverted managers as shown in tables 5 (Pearson's correlation coefficient $=.349, \mathrm{p}<0.05)$, table $7(\Delta \mathrm{R} 2=.127$ and $\Delta \mathrm{F}=5.652, \mathrm{p}<0.05)$ and table 11 $(B=.311, p<0.05)$. Higher percentage of "Defect" wastes have also been found to be done by Introverted than Extroverted managers (Pearson's correlation coefficient $=.417, p<0.01$ : table 5; $\Delta \mathrm{R} 2=.128$ and $\Delta \mathrm{F}=5.881, \mathrm{p}<0.05$ : table $7 ; \mathrm{B}=.368, \mathrm{p}<0.05$ : table 11). Regarding the type of waste "Movement", correlations in table 5 indicating that the introverted manager is correlated positively with the number of wastes (Pearson's correlation coefficient $=.318, \mathrm{p}<0.05)$. Similarly, $\mathrm{EI}$ is significant in Hierarchical regression analysis $(\Delta \mathrm{R} 2=.094$ and $\Delta \mathrm{F}=4.886, \mathrm{p}<0.05$ : table 7$)$. Unfortunately, when the attitudes are combined with the remaining personality traits (Table 11 ), the extroverted/introverted attitude is overshadowed by the thinking/feeling attitude. Thus, there is some support for $\mathrm{H} 2$.

\subsubsection{The effect of the judging-perceiving dimension on project performance}

$\mathrm{H} 3$ stated that Judging project managers exhibit higher project performance, in terms of (a) \% delay, (b) over-budget and (c) waste time, than Perceiving project managers.

The correlation between project delay and JP was significant and negative (Pearson's correlation coefficient $=-.361, \mathrm{p}<0.05$, two tailed test: table 4 ). This result indicates that judging managers made significantly more delay than perceiving managers. Similarly, JP is significant and negative in either of the two regressions $(\Delta R 2=.137 p<0.01$ and $\Delta F=8.188$, $p<0.005$ : table 6$)(B=-.372, p<0.05$, two-tailed test: table 10$)$. The direction of the parameter estimates (table 10 ) supported the opposite of hypothesis $\mathrm{H} 3(\mathrm{a})$ ). Thus, the results obtained show that Perceiving managers have a significantly lower delay in comparison with Judging ones.

The correlation between over-budget and JP was also significant and negative (Pearson's correlation coefficient $=-.508, \mathrm{p}<0.01$, two tailed test: table 4$)$. Similarly, JP is significant and negative in either of the two regressions $(\Delta \mathrm{R} 2=.184 \mathrm{p}<0.05$ and $\Delta \mathrm{F}=8.658, \mathrm{p}<0.05$ : table 6$)(B=-.418, p<0.05$, two-tailed test: table 10$)$. These results supported the opposite of hypothesis $\mathrm{H} 3(\mathrm{~b})$. Thus, the results obtained show that Perceiving managers have a significantly lower over-budget in comparison with Judging ones.

The correlation between Waste time and JP was not significant (table 5). Similarly, JP is not significant in either regression (tables 7 and 11). Thus, $\mathrm{H3}$ (c) is not supported.

$\mathrm{H} 4$ stated that there is a relation between type of waste and judging/perceiving personality of project managers. Correlations in table 5 indicating that judging manager is correlated positively only with the "Over-processing" number of wastes (Pearson's correlation coefficient 
$=.359, \mathrm{p}<0.05)$. This result provides initial support of the statement: "over-processing" wastes are more frequently done by Judging than Perceiving managers. Unfortunately JP is not significant in either of the two regressions (tables 7 and 11). These results indicate that there is not a significant cause-effect relation between the "over-processing" number and the attitude JP. Thus, H4 is not supported.

\subsubsection{The effect of the sensing-intuition dimension on project performance}

H5 stated that Intuitive project managers exhibit higher project performance, in terms of (a) $\%$ delay, (b) over-budget and (c) waste time, than Sensing project managers.

The correlation between project delay and SN was not significant (table 4). Similarly, SN is not significant in either of the two regressions (tables 8 and 10). Thus, H5(a) is not supported.

The correlation between over-budget and SN was significant and positive (Pearson's correlation coefficient $=.339, \mathrm{p}<0.05$ : table 4 ), but $\mathrm{SN}$ is not significant in either of the two regressions (tables 8 and 10). These results indicate that there is not a significant cause-effect relation between the dependent variable "over-budget" and the attitude SN. Thus, H5(b) is not supported.

Moreover SN is not significant for the dependent variables "waste time" and "type of wastes" (tables 5, 9 and 11). Thus, $\mathrm{H} 5$ (c) and $\mathrm{H} 6$ are not supported.

\subsubsection{The effects of the thinking-feeling dimension on project performance}

$\mathrm{H} 7$ stated that thinking project managers exhibit higher project performance, in terms of (a) \% delay, (b) over-budget and (c) waste time, than feeling project managers.

Correlation in Table 4 indicates that managers' TF is not correlated with project delay. Similarly, TF is not significant in the two regressions (tables 8 and 10). Thus, $H 7(a)$ is not supported.

Moreover, the correlation between the dependent variables over-budget and waste time with TF was not significant (tables 4 and 5). Similarly, TF is not significant in either of the two regressions (tables 8,9 and 10 ). Thus, $\mathrm{H7}$ (b) and $\mathrm{H7}$ (c) are not supported.

$\mathrm{H} 8$ stated that there is a relation between type of waste and thinking/feeling personality of project managers. The type of waste "Movement" is done significantly more by thinking than feeling managers as shown in tables 5 (Pearson's correlation coefficient $=-.379, p<0.05$ ). The two regressions confirm this result: table $9(\Delta \mathrm{R} 2=.092$ and $\Delta \mathrm{F}=5.327, \mathrm{p}<0.05)$ and table $11(B=-.356, p<0.05)$. 
Table 12 summarizes the hypothesis testing results.

\begin{tabular}{|c|c|c|}
\hline \multicolumn{2}{|c|}{ Hypothesis } & Outcome \\
\hline \multirow{3}{*}{$\begin{array}{l}\text { H1: Extroverted project managers carry } \\
\text { out projects that show: }\end{array}$} & $\begin{array}{l}\text { (a) lower delay than } \\
\text { introverted project managers }\end{array}$ & Supported \\
\hline & $\begin{array}{l}\text { (b) lower over-budget than } \\
\text { introverted project managers }\end{array}$ & Not supported \\
\hline & $\begin{array}{l}\text { (c) lower waste time than } \\
\text { introverted project managers. }\end{array}$ & Supported \\
\hline \multicolumn{2}{|c|}{$\begin{array}{l}\mathrm{H} 2: \text { There is a relation between the type of waste and the } \\
\text { extroverted/introverted personality of project managers }\end{array}$} & $\begin{array}{l}\text { Relation between } \\
\text { introverted managers } \\
\text { with type of wastes: } \\
\text { "Over-processing" and } \\
\text { "Defect" }\end{array}$ \\
\hline \multirow{3}{*}{$\begin{array}{l}\text { H3: Judging project managers carry out } \\
\text { projects that show }\end{array}$} & $\begin{array}{l}\text { (a) lower delay than perceiving } \\
\text { project managers }\end{array}$ & $\begin{array}{l}\text { Supported the opposite } \\
\text { of hypothesis } \mathrm{H} 3 \mathrm{a}\end{array}$ \\
\hline & $\begin{array}{l}\text { (b) lower over-budget than } \\
\text { perceiving project managers }\end{array}$ & $\begin{array}{l}\text { Supported the opposite } \\
\text { of hypothesis H3b }\end{array}$ \\
\hline & $\begin{array}{l}\text { (c) lower waste time than } \\
\text { perceiving project managers. }\end{array}$ & Not supported. \\
\hline \multicolumn{2}{|c|}{$\begin{array}{l}\text { H4: There is a relation between the type of waste and the } \\
\text { judging/perceiving personality of project managers }\end{array}$} & Not supported. \\
\hline \multirow{3}{*}{$\begin{array}{l}\text { H5: Intuitive project managers carry out } \\
\text { projects that show }\end{array}$} & $\begin{array}{l}\text { (a) lower delay than sensing } \\
\text { project managers }\end{array}$ & Not supported. \\
\hline & $\begin{array}{l}\text { (b) lower over-budget than } \\
\text { sensing project managers }\end{array}$ & Not supported. \\
\hline & $\begin{array}{l}\text { (c) lower waste time than } \\
\text { sensing project managers. }\end{array}$ & Not supported. \\
\hline \multicolumn{2}{|c|}{$\begin{array}{l}\text { H6: There is a relation between the type of waste and the intuitive/sensing } \\
\text { personality of project managers }\end{array}$} & Not supported. \\
\hline \multirow{3}{*}{$\begin{array}{l}\text { H7: Thinking project managers carry out } \\
\text { projects that show }\end{array}$} & $\begin{array}{l}\text { (a) lower delay than feeling } \\
\text { project managers }\end{array}$ & Not supported. \\
\hline & $\begin{array}{l}\text { (b) lower over-budget than } \\
\text { feeling project managers }\end{array}$ & Not supported. \\
\hline & $\begin{array}{l}\text { (c) lower waste time than } \\
\text { feeling project managers. }\end{array}$ & Not supported. \\
\hline \multicolumn{2}{|c|}{$\begin{array}{l}\text { H8: There is a relation between the type of waste and the thinking/feeling } \\
\text { personality of project managers }\end{array}$} & $\begin{array}{l}\text { Relation between } \\
\text { thinking managers with } \\
\text { type of waste: } \\
\text { "Movement" }\end{array}$ \\
\hline
\end{tabular}

Table 12 . Summary results of hypothesis testing

\section{Discussion}

This paper illustrates a roadmap for how Value Stream Mapping (VSM) can be an important tool to define, analyze, and quantify waste, such as waiting and defects, as shown in the example (see appendix A). Particularly this research highlights that "over-processing" is the most important waste made by managers of this corporation. Basically, managers carried out activities that customers do not require. The most common errors are: paper instructions that will never be read, having 4 different spreadsheets in the office to record the same information, having both electronic records and paper records or to creating packaging that is two, three or even four times as big as the product. In all these cases, managers take more time, do more things and use more resources without adding lasting value to the customer. The "waiting" wastes have also been frequently done by managers. Some root causes of waiting are: unbalanced work load, misuse of automation, quality problems and unleveled 
scheduling. Some symptoms that the panel highlighted were: under-utilization of resources, increase in investment, idle equipment and unnecessary testing.

Regarding managers' personality, the results show that potentially two of the four Jungian personality dimensions (extroversion-introversion and judging-perceiving but not sensingintuition nor thinking-feeling) significantly affect managerial end-users' abilities to manage projects. This work highlights that Extrovert managers provided better performance in comparison with Introvert ones, in terms of both traditional and VSM indexes. The correlation between personality type and type of waste provides the same information: introverted managers more often make "over-processing" and "defect" errors. In our opinion, these results obtained from Extrovert and Introvert managers, are connected to the fact that project managers must be able to communicate in many ways with many people. We noticed that Extrovert managers often work with five to nine people every day and they are typically early in the office or late out of the office, doing their solitary work out of hours or at weekends. The extroversion-introversion (E-S) dichotomy assesses whether a person prefers to be either extroverted or introverted, thus focusing their attention and obtaining their energy for daily activities. According to the literature, we notice that Extrovert managers are more connected to the outer world of people, places, and things and they are considered sociable, gregarious, and interactive. Introverts preferred solitude to recover energy, oriented towards the inner world of concepts and ideas.

This work also highlights that Perceiving managers provide better performance, in terms of traditional performance indexes, in comparison with Judging ones. The judging-perceiving (J-P) dichotomy reflects processes which people use when they interact and orient themselves with others in the world. It reflects lifestyle and work habits. Individuals who choose closed over open options are likely to be the judging type. They feel a sense of urgency to take a pending decision and they like to develop, schedule and implement plans. They often feel relief after making a decision or constructing a plan of action. Individuals who prefer to leave decisions open and thoughtfully reflect on options are described as perceiving. They are highly adaptable to changing environments, they find happiness in new tasks or opportunities, and they dislike routine. However, they prefer to keep their options open with a "wait and see" attitude. During this work, we noticed the natural tendency of many project managers to assume the Judging personality type. Given the constant need to take decisions, Judging personalities are naturally drawn to it. Despite this aspect, the management of a project is a complex activity and some characteristics of Perceiving, or data gathering, are necessary for success. The ability to operate in both spheres is necessary. The Judging manager meets failure if he or she can not take the time to gather required information, making decisions too quickly and with too little information. The correlation between personality type and wastes provides the same information. Judging managers make "over-processing" errors more often. This performance is essentially due to their failure in team building. 
Once corporation has a better understanding of the characteristics that lead to more successful information retrieval, training programs can be tailored toward managerial end-users with different cognitive styles. The Jungian system of personality classification asserts that no individual is a "pure" type (Jung, 1971). Each individual possesses the ability to function in all of the traits that makeup the types, but tends to prefer one trait in each of the fourdimensional pairs. By analyzing the personality traits that lead to best performance, training programs can be developed to help people with other personality traits to learn how to use some of their non-preferred traits and thereby provide higher performance. By taking this duality into consideration, trainers will be better able to design programs that enable managerial end-users with the non-preferred traits to learn how to adopt the most appropriate approach when managing projects.

\section{Conclusions}

This research could provide insight useful to develop proactive approaches to prevent project failures, including the creation of more effective messages and methods to help companies to make the best choices. For instance, many managers who come from accounting backgrounds are typically ST] personality types. This personality type prefers to obtain data through direct or objective perceptions. According to the MBTI theory, however, those individuals who have a preference for the sensing trait possess the intuition trait too. A person may simply need some training to become proficient at using a less preferred dimension of their personality. This training would allow them to better use another facet of their personality and thus to manage projects more accurately.

Secondly, this research has implications for staffing. During the last decade, one of the fastest growing aspects in human resource management has been in the area of personality testing as employees are selected based on whom best fits the required profile (Rolfe \& McPherson, 1995). One issue closely related to staffing is the growing trend in the outsourcing of selected aspects of management via short-term contracts (Feltham \& Hughes, 1999). This research would allow corporation to better match the short-term organizational needs with appropriate personality types.

The findings of this work strongly support the hypothesis according to which the project manager needs to exhibit an extroverted and perceiving personality in conjunction with mastering project management discipline. This is true even if each dimension highlights just the dominant personality trait for a person. An Extrovert is still capable of Introverted thought. Personality exists on a continuum, and indeed most personality tests provide a rating to judge where each person falls on the scale. There is no fail-safe method to pre-select the ultimate project manager. If there were, no one would call it the "accidental profession". The typical 
project manager had a number of positions before becoming a project manager, gaining experience in an industry before being a manager.

We conclude highlighting that not each personality is suited to a project leader job. Using Myers-Briggs Type Indicator notation, we can show that only a few combinations are compatible with various management styles. Future research could be conducted in order to better understand the impact of the extroverted-introverted personality dimension. Such future research could examine the impact of the EI dimension on the capacity to manage large teams as well as on the formulation of the project cost baseline. Although the results reported to date have been implemented in a European corporation, replications of this study in other cultures and other industries would be very useful to verify these findings.

Regarding the limitations of this work it is necessary to highlight that we collected data from project managers in a retrospective way. While we believe that several aspects of our data collection effort helped enhance the accuracy of the results, future research could conduct realtime case study research to get more detailed insights into the proposed relationships and avoid retrospective bias. Moreover we focused on a single respondent, the project manager. This helped us ensure that their interpretations played an important role in product development. But, we cannot examine the opinion of team members that could be different from project manager's opinion regarding some questions.

\section{References}

Bannerman, P.L. (2008). Defining project success: a multilevel framework. Proceedings PMI Research Conference, Warsaw, Poland, July 13-16.

Bar-On, R. (2000). Emotional and social intelligence: Insights from the emotional quotient inventory. In R. Bar-On \& J. Parker (Eds.), The handbook of emotional intelligence: Theory, development, assessment, and application at home, school, and in the workplace (1st ed., pp. 363-388). San Francisco, CA: Jossey-Bass.

Barrick, M.R., \& Mount, M.K. (1991). The Big Five personality dimensions and job performance: A meta-analysis. Personnel Psychology, 44, 1-26. http://dx.doi.org/10.1111/j.17446570.1991.tb00688.x

Bauch, C. (2004). Lean Product Development: Making waste transparent. Massachusetts Institute of Technology. PhD thesis August 2004.

Black, K, \& Slaker, R. (2004). Project performance: implications of personality preferences and double loop learning. Journal of American Academy of Business, 4(1/2), 292-297. 
Bowen, P.L., Ferguson, C.B., Lehmann, T.H., \& Rohde, F.H. (2003). Cognitive style factors affecting database query performance. International Journal of Accounting Information Systems, 4, 251-273. http://dx.doi.org/10.1016/j.accinf.2003.05.002

Choi, K.S., Deek, F.P., \& Im, I. (2008). Exploring the underlying aspects of pair programming: The impact of personality. Information and Software Technology, 50, 1114-1126. http://dx.doi.org/10.1016/j.infsof.2007.11.002

Crawford, C.M. (1987). New product failure rates: a reprise. Research management. New York, NY: Inst, ISSN 0034-5334, ZDB-ID 3901105. 30.1987, (4), 20-24.

http://dx.doi.org/10.1126/science.237.4810.20

Davis, S.A. (2011). Investigating the Impact of Project Managers' Emotional Intelligence on Their Interpersonal Competence. Project Management Journal, 42(4), 37-57. http://dx.doi.org/10.1002/pmj.20247

De Jong, R.D., Bouhuys, S.A., \& Barnhoorn, J.C. (1999). Personality, self-efficacy and functioning in management teams: a contribution to validation. International Journal of Selection and Assessing, 7(1), 46-49. http://dx.doi.org/10.1111/1468-2389.00103

Dolfi, J., \& Andrews, E. (2007). The Subliminal Characteristics Of Project Managers: An Exploratory Study Of Optimism Overcoming Challenge In The Project Manager Work Environment. International Journal of Project Management, 25, 674-682. http://dx.doi.org/10.1016/j.ijproman.2007.02.002

Farris, J., Groesbeck, R.L., Van Aken, E.M., \& Letens, G. (2006). Evaluating the relative performance of engineering design projects: a case study using data envelopment analysis. IEEE Transaction Engineering Management, 53(3), 471-482.

http://dx.doi.org/10.1109/TEM.2006.878100

Feltham, R., \& Hughes, D. (1999). Interim Managers: Distinguishing Personality Characteristics of Managers on Short-term Contracts. International Journal of Selection and Assessment, 7(4), 209-214. http://dx.doi.org/10.1111/1468-2389.00121

Gehring, D. (2007). Applying traits theory of leadership to project management. Project Management Journal, 38(1), 44-54.

Gillard, S., \& Price, J. (2005). The competencies of effective project managers: A conceptual analysis. International Journal of Management, 22(1), 48-53.

Harrison, F., \& Lock, D. (2004). Advanced Project Management a Structured Approach. Gower Publishing, Ltd. pp. 34.

Hirsh, S., \& Kummerow, J. (1997). Life types: Understanding yourself and make the most of who you are. New York: Warner Books. 
Jablokow, K.W., \& Booth, D.E. (2006). The Impact and Management of Cognitive Gap in High Performance Product Development Organizations. Journal of Engineering and Technology Management, 23, 313-336. http://dx.doi.org/10.1016/j.jengtecman.2006.08.003

Jeong, K.J., \& Phillips, D.T. (2011). Application of a concept development process to evaluate process layout designs using value stream mapping and simulation. Journal of Industrial Engineering and Management, 4(2), 206-230. http://dx.doi.org/10.3926/jiem.2011.v4n2.p206-230

Johnson, W.L., Mauzey, E., Johnson, A.M., Murphy, S.D., \& Zimmerman, K.J. (2001). A higher order analysis of the factor structure of the Myers-Briggs Type Indicator. Measurement and Evaluation in Counseling and Development, 34, 96-108.

Jung, C.G. (1971). Psychological types. In R. F. C. Hull (Eds.), The collected works of Carl Gustav Jung, Vol. 6. Princeton, NJ: Princeton University Press (Original work published in 1921).

Mayer, J., Salovey, P., \& Caruso, D. (2000). Models of emotional intelligence. In R. J. Sternberg (Ed.), Handbook of intelligence (pp. 396-420). New York: Cambridge University Press. http://dx.doi.org/10.1017/CBO9780511807947.019

Meza, D., \& Jeong, K.Y. (2013) Measuring efficiency of lean six sigma project implementation using data envelopment analysis at NASA. Journal of Industrial Engineering and Management, 6(2), 401-422. http://dx.doi.org/10.3926/jiem.582

Mills, J., Robey, D., \& Smith, L. (1985). Conflict handling and personality dimension of project management personnel. Psychological Reports, 57, 1135-1143. http://dx.doi.org/10.2466/pro.1985.57.3f.1135

Mohanty, A., Mishra, J., \& Satpathy, B. (2011). Activity modes selection for project crashing through deterministic simulation. Journal of Industrial Engineering and Management, 4(4), 610-623. http://dx.doi.org/10.3926/jiem.224

Mullaly, M.E., \& Thomas, J. (2004). Linking Personality and Project Success: Exploring the Inter-relationship of Psychological Type and Project Manager Competency, presented at IRNOP VI, Turku, Finland.

Myers, I.B., \& Myers, P.B. (1980). Gifts differing: understanding personality type. Palo Alto, CA: Davies-Black Publishing.

Othman, M., Gouw, G.J., \& Bhuiyan, N. (2012). Workforce scheduling: A new model incorporating human factors. Journal of Industrial Engineering and Management, 5(2), 259-284. http://dx.doi.org/10.3926/jiem.451 
Prabhakar, G.P. (2008). What is project success: a literature review. International Journal of Business Management, 3(9), 3-10.

Purcell, J., \& Hutchinson, S. (2007). Front-line managers as agents in the HRM-performance causal chain: theory, analysis and evidence. Human Resource Management Journal, 17(1), 3-20. http://dx.doi.org/10.1111/j.1748-8583.2007.00022.x

Rother, M., \& Shook, J. (1999). Learning to See. Version 1.2. Brookline, MA: Lean Enterprise Institute.

Rolfe, I., \& McPherson, J. (1995). Formative assessment: how am I doing?. Lancet, 345, 837-839. http://dx.doi.org/10.1016/S0140-6736(95)92968-1

Shenhar, A.J., \& Wideman, R.M. (2000). Matching project management style with project type for optimum success. PMForum internet site at www.pmforum.com, also found at http://www.maxwideman.com/papers/profiles/observations.htm.

Smith, L.W. (2001). The effects of project manager personality profiles on projects. Proceedings of the Project Management Institute Annual Seminars and Symposium, Nashville, TN.

Sprague, M.M. (1997). Personality type matching and student teacher evaluation. Contemporary Education, 69, 54-57.

Tett, R.P., Jackson, D.N., \& Rothstein, M. (1991). Personality measures as predictors of job performance: A meta-analytic review. Personnel Psychology, 67, 737-743.

Thomas, G., \& Fernandez, W. (2008). Success in IT projects: a matter of definition?. International Journal of Project Management, 26(7), 733-742.

http://dx.doi.org/10.1016/j.ijproman.2008.06.003

Turner, J.R., \& Muller, R. (2006). Choosing Appropriate Project Managers. Matching Their Leadership Style to the Type of Project. Newtown Square, PA: The Project Management Institute.

Wheeler, P. (2001). The Myers-Briggs Type Indicator and applications to accounting education and research. Issues in Accounting Education, 16(1), 123-150.

http://dx.doi.org/10.2308/iace.2001.16.1.125 


\section{Appendix A. Application of VSM techniques in a project of Hydraulic System Development}

This project has been developed by a firm involved in the production of thin film silicon solar modules. The firm needed to substitute the hydraulic system, which opens the chamber's lid. The opening system consists of a double hydraulic cylinder, which works with a short lever on the lid's lateral edge to turn it.

The project manager, before beginning the project, filled out a copy of the 93-item MBTI form $M$ and the result was the personality Extraverted, Intuition, Thinking and Judging (ENTJ).

\section{PROJECT DESCRIPTION}

The opening system (called TOC) was not initially developed by Oerlikon Solar. When the company bought the project, it received the whole digital and paper documentation but no one knew if the hydraulic system was oversized, if the cylinder's stroke was completely used, or if the leverage geometry was appropriate. During the Retrieving Information step, many aspects have been verified: for instance, the match between documents and installed parts have been checked, the parts' specifications requested to the supplier, etc. This activity has been performed in order to generate missing "know-how". After this step, Reverse Engineering is necessary to make up for the lack of "know-why". While many parts have a clear function in the system, there are still some open issues. Design criterions were not available, so reverse engineering on existing parts was mandatory. This activity took a long time due to the pointbased procedure: at first hypothesis is generated then verification is shown, in which the results are compared with expected values, and in case of failure the process is looped. It has been possible to apply a Fine Tuning to the mechanism only at the end of reverse engineering, when a complete view over the assembly was available. Once the opening mechanism has an optimal setup, then actuators are properly sized. Lever's geometry provides the needed stroke, and needed force. This force can be delivered with several combinations of the piston's size and pressure. Embodiment is a critical phase: it must be verified that actuators could be mounted in the relative hollow. This has been a long procedure: the whole TCO's assembly must be considered including cables, wires, pipes, valves, accessories. A complete and detailed tridimensional-model is then put in motion in order to verify that actuators do not hit anything during movement. At the end of this long work, a Design Review takes place. At this point, the process splits in to two branches: 1) Pneumatic System development (multi-lever mechanism) and 2) Hydraulic System's cost reduction. The second solution has two ways:

- Actuators number reduction: it consists in maintaining the size of each component (valves, cylinders, pipes, ...) using only one cylinder per chamber. 
- Actuator size reduction: it consists in downscaling every component (valves, cylinders, pipes, ...) while maintaining the current scheme.

The project manager decided to create two teams; each one took care of a concept. At the end, the pneumatic project was frozen due to a problem in the pressure boost while the second concept (actuator size reduction) showed better performance.

\section{VALUE STREAM MAPPING OF THE PROJECT}

Once the project was finished, a panel of experts drew the Value Stream Mapping (VSM) of that project identifying the added value time of the activities (VA/T) and the type of wastes. $\mathrm{VA} / \mathrm{T}$ value is the activity time that provides value to the customer (see figure 2 ).

The observed lead-time of the project is 74 days (this is the real project duration) while the observed value-added time is 33 days. As shown in figure 2, the panel of experts identified several "over-processing", "movement", "waiting" wastes. As mentioned before, the process started with "Information retrieving" and "Reverse engineering". Both activities generated a double waste:

- Waste of resources: people are committed to looking for information which was supposed to be available.

- Waste of time: the real phase of development had to wait, so lead-time grew.

According to our classification of wastes these issues correspond to "Information hunting" (3A of table 1).

Going forward into the process, there is something even more evident: a "dead-branch". It corresponds to the analysis of multi-lever solution. Since this part of the process brought no significant results, it was a non-added-value activity. Moreover, the Designer himself checked the correct values for air pressure in the distribution system. Although this step stopped the analysis before wasting more time and resources, there was something wrong with it. Each supplier tried to improve his product's performance, but this was not the case: probably the supplier forwarded nominal values. Accuracy of data could have been easily verified with a phone-call or with an email. Clearly, this branch is characterized by "Unnecessary features and processes" (4B of table 1). We can easily extend these considerations to the analysis of the single-actuator's layout. In this case, a formal evaluation would have avoided the activities. The process ends with some more "Information hunting" (3A) and "People waiting for information" (1B). In comparison with previously described problems, these issues are not very significant and could also be avoided. 


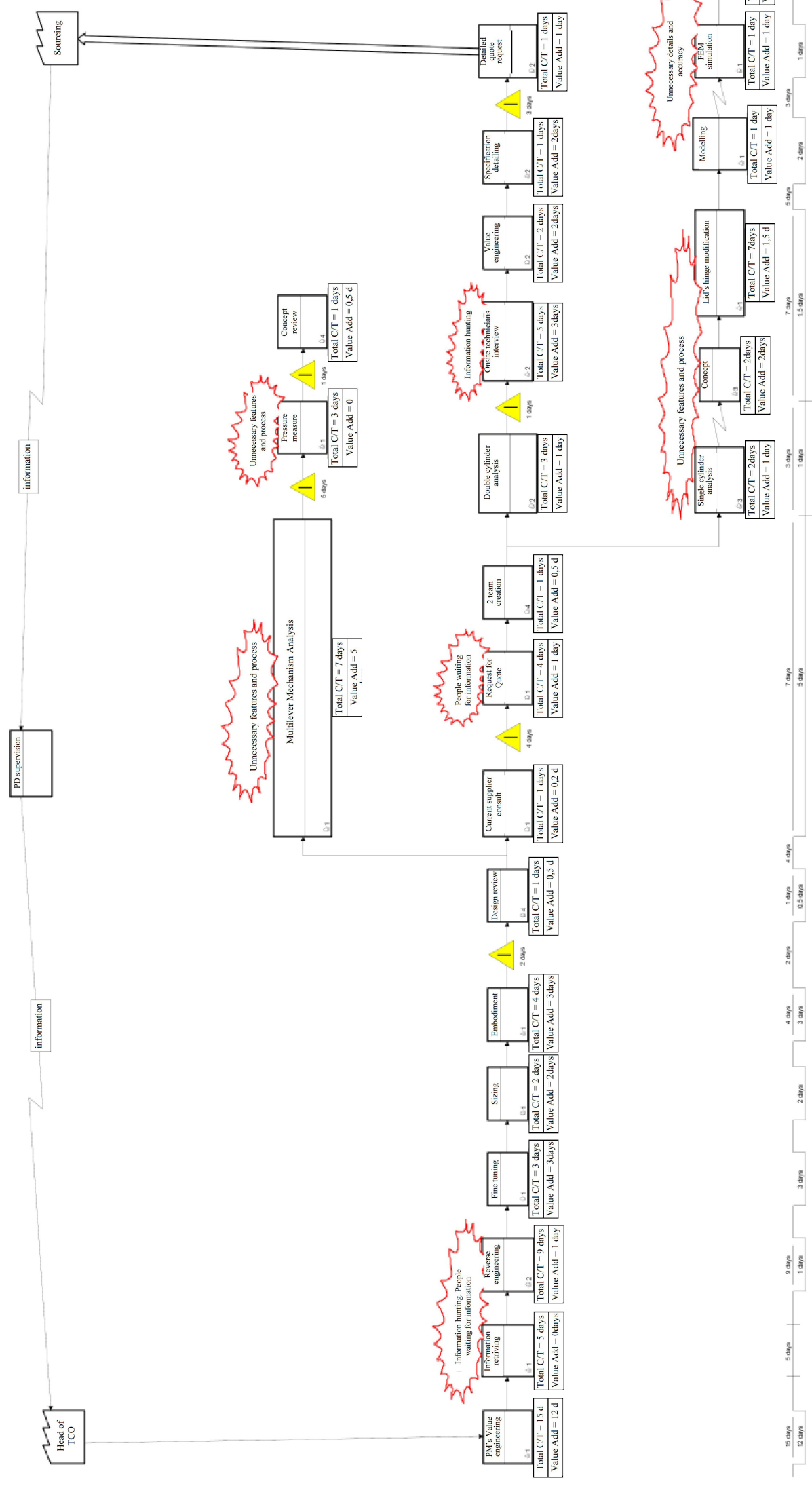

Figure 2. VSM of the project 
Appendix B

\begin{tabular}{|c|c|c|c|c|c|c|c|c|c|c|c|c|c|}
\hline $\begin{array}{l}\text { Project } \\
\text { number }\end{array}$ & $\begin{array}{c}\text { Manager' } \\
\text { personality }\end{array}$ & $\underset{\mathrm{EI}}{\text { Managers' }}$ & $\begin{array}{l}\text { Managers' } \\
\text { SN }\end{array}$ & $\begin{array}{c}\text { Managers' } \\
\mathrm{TF}\end{array}$ & $\begin{array}{l}\text { Managers' } \\
\text { JP }\end{array}$ & $\begin{array}{c}\text { Gender } \\
(1=\text { male; } \\
2=\text { female })\end{array}$ & Age & $\begin{array}{l}\text { Company } \\
\text { sector } \\
(\mathrm{PP}=1 ; \\
\mathrm{MS}=2 ; \\
\mathrm{PD}=3 ; \\
\mathrm{CE}=4)\end{array}$ & $\begin{array}{l}\text { Human } \\
\text { resources } \\
\text { involved }\end{array}$ & $\begin{array}{c}\text { planned } \\
\text { project } \\
\text { duration } \\
\text { (days) }\end{array}$ & $\begin{array}{c}\text { real } \\
\text { project } \\
\text { duration } \\
\text { (days) }\end{array}$ & DELAY & $\begin{array}{l}\text { Over- } \\
\text { budget }\end{array}$ \\
\hline 1 & ESFP & -16 & -18 & 12 & 17 & 1 & 39 & 1 & 4 & 60 & 75 & 0,25 & 0,20 \\
\hline 2 & ISFJ & 21 & -23 & 20 & -8 & 1 & 44 & 2 & 3 & 80 & 98 & 0,23 & 0,40 \\
\hline 3 & ISTP & 30 & -9 & -7 & 12 & 1 & 51 & 4 & 6 & 120 & 156 & 0,30 & 0,15 \\
\hline 4 & ESTJ & -27 & -15 & -23 & -6 & 2 & 48 & 3 & 4 & 100 & 122 & 0,22 & 0,50 \\
\hline 5 & ESFP & -21 & -26 & 16 & 23 & 1 & 45 & 3 & 6 & 80 & 96 & 0,20 & 0,30 \\
\hline 6 & ENTJ & -17 & 11 & -12 & -7 & 2 & 39 & 4 & 2 & 60 & 70 & 0,17 & 0,55 \\
\hline 7 & ENTP & -14 & 5 & -33 & 15 & 1 & 61 & 3 & 4 & 100 & 113 & 0,13 & 0,28 \\
\hline 8 & ESFP & -15 & -33 & 22 & 31 & 1 & 38 & 4 & 5 & 100 & 110 & 0,10 & $-0,15$ \\
\hline 9 & ISFJ & 22 & -25 & 10 & -21 & 2 & 50 & 2 & 4 & 80 & 110 & 0,38 & 0,25 \\
\hline 10 & INTP & 20 & 13 & -24 & 2 & 1 & 62 & 3 & 7 & 120 & 158 & 0,32 & 0,40 \\
\hline 11 & ESTP & -11 & -10 & -16 & 23 & 2 & 36 & 4 & 4 & 100 & 130 & 0,30 & 0,20 \\
\hline 12 & ISTP & 18 & -8 & -5 & 16 & 2 & 44 & 2 & 3 & 60 & 84 & 0,40 & 0,38 \\
\hline 13 & ISTP & 27 & -31 & -28 & 9 & 1 & 39 & 3 & 5 & 80 & 106 & 0,33 & 0,12 \\
\hline 14 & ESTP & -26 & -27 & -11 & 20 & 1 & 53 & 1 & 5 & 100 & 113 & 0,13 & 0,00 \\
\hline 15 & ESTJ & -22 & -12 & -3 & -13 & 1 & 38 & 3 & 5 & 120 & 156 & 0,30 & 0,24 \\
\hline 16 & ESFJ & -3 & -6 & 19 & -20 & 1 & 45 & 3 & 4 & 60 & 72 & 0,20 & 0,15 \\
\hline 17 & ENTJ & -10 & 18 & -24 & -4 & 1 & 47 & 1 & 3 & 60 & 74 & 0,23 & 0,28 \\
\hline 18 & ENTP & -12 & 13 & -13 & 30 & 1 & 42 & 3 & 4 & 75 & 95 & 0,27 & 0,10 \\
\hline 19 & INTJ & 37 & 9 & $\begin{array}{l}-7 \\
\end{array}$ & -23 & 2 & 50 & 3 & 3 & 80 & 98 & 0,23 & 0,15 \\
\hline 20 & ESFP & -6 & -17 & 9 & 14 & 1 & 49 & 3 & 5 & 100 & 130 & 0,30 & 0,45 \\
\hline 21 & INT] & 26 & 22 & -16 & -33 & 2 & 52 & 4 & 5 & 120 & 178 & 0,48 & 0,55 \\
\hline 22 & ISTP & 13 & -21 & -15 & 5 & 1 & 54 & 2 & 4 & 100 & 132 & 0,32 & 0,20 \\
\hline 23 & ESTP & -10 & -37 & -2 & 34 & 1 & 39 & 1 & 4 & 80 & 80 & 0,00 & 0,15 \\
\hline 24 & ESTJ & -8 & -20 & -9 & -22 & 1 & 42 & 4 & 4 & 120 & 145 & 0,21 & 0,38 \\
\hline 25 & ESFJ & -17 & -9 & 14 & -4 & 2 & 47 & 2 & 4 & 100 & 140 & 0,40 & 0,25 \\
\hline 26 & ESFP & -29 & -11 & 26 & 1 & 2 & 49 & 1 & 6 & 100 & 125 & 0,25 & 0,15 \\
\hline 27 & ESFJ & -10 & -14 & 6 & -21 & 1 & 50 & 2 & 6 & 80 & 116 & 0,45 & 0,35 \\
\hline 28 & ENTP & -37 & 8 & -11 & 15 & 1 & 52 & 3 & 5 & 75 & 75 & 0,00 & 0,20 \\
\hline 29 & ENTJ & -22 & 25 & -5 & -38 & 1 & 53 & 1 & 3 & 100 & 100 & 0,00 & 0,40 \\
\hline 30 & ISF] & 28 & -3 & 23 & -15 & 1 & 39 & 4 & 4 & 120 & 192 & 0,60 & 0,45 \\
\hline 31 & ISTP & 36 & -6 & -18 & 37 & 2 & 50 & 3 & 4 & 80 & 100 & 0,25 & 0,15 \\
\hline 32 & ISF] & 32 & -18 & 13 & -16 & 1 & 42 & 1 & 3 & 60 & 72 & 0,20 & 0,32 \\
\hline 33 & ESFP & -21 & -11 & 22 & 10 & 1 & 46 & 3 & 3 & 80 & 80 & 0,00 & 0,26 \\
\hline 34 & ESFJ & -37 & -23 & 30 & -6 & 2 & 36 & 2 & 4 & 90 & 126 & 0,40 & 0,33 \\
\hline 35 & ESTJ & -12 & -9 & -21 & -14 & 1 & 41 & 4 & 6 & 120 & 175 & 0,46 & 0,40 \\
\hline 36 & INTP & 37 & 13 & $\begin{array}{l}-7 \\
\end{array}$ & 16 & 2 & 46 & 2 & 5 & 100 & 140 & 0,40 & 0,35 \\
\hline 37 & ISTP & 25 & -8 & -16 & 28 & 1 & 53 & 1 & 5 & 80 & 85 & 0,06 & 0,00 \\
\hline 38 & ESFJ & -22 & -14 & 5 & -10 & 1 & 56 & 2 & 4 & 100 & 130 & 0,30 & 0,12 \\
\hline 39 & ESFP & -15 & -30 & 24 & 25 & 1 & 46 & 3 & 4 & 100 & 100 & 0,00 & 0,35 \\
\hline 40 & ESFJ & -9 & -10 & 13 & -5 & 2 & 58 & 2 & 5 & 120 & 170 & 0,42 & 0,28 \\
\hline
\end{tabular}

Table 13(a). Data collected

\begin{tabular}{|c|c|c|c|c|c|c|c|c|c|c|c|c|}
\hline $\begin{array}{l}\text { Project } \\
\text { number }\end{array}$ & $\begin{array}{c}\text { Value } \\
\text { added } \\
\text { time } \\
\text { of the } \\
\text { project } \\
(\mathrm{VA} / \mathrm{T})\end{array}$ & $\begin{array}{c}\text { waste } \\
\text { time }\end{array}$ & Waiting & $\begin{array}{c}\text { Transport/ } \\
\text { handoffs }\end{array}$ & Movement & $\begin{array}{c}\text { Over } \\
\text { processing }\end{array}$ & Inventory & $\begin{array}{l}\text { Overproduction/un- } \\
\text { synchronized } \\
\text { processing }\end{array}$ & Defects & Reinvention & $\begin{array}{c}\text { Lack of } \\
\text { discipline }\end{array}$ & $\begin{array}{l}\text { Limited } \\
\text { IT } \\
\text { resources }\end{array}$ \\
\hline 1 & 42 & 33 & 1 & 0 & 0 & 2 & 0 & 0 & 0 & 0 & 0 & 0 \\
\hline 2 & 61 & 44 & 2 & 1 & 1 & 1 & 0 & 1 & 0 & 0 & 0 & 0 \\
\hline 3 & 78 & 78 & 1 & 0 & 2 & 2 & 1 & 0 & 1 & 0 & 0 & 1 \\
\hline 4 & 70 & 52 & $\frac{1}{1}$ & $\frac{5}{2}$ & $\frac{2}{2}$ & 1 & $\frac{1}{0}$ & 0 & 0 & 0 & 0 & $\frac{1}{1}$ \\
\hline 5 & 45 & 51 & 2 & 0 & 1 & 0 & 0 & 1 & 0 & 0 & 0 & 0 \\
\hline 6 & 35 & 35 & 1 & 1 & 1 & 2 & 0 & 0 & 1 & 0 & 0 & 0 \\
\hline 7 & 65 & 48 & 1 & 1 & 0 & 2 & 0 & 0 & 0 & 1 & 0 & 0 \\
\hline 8 & 65 & 45 & 0 & 1 & 1 & 0 & 0 & 0 & 0 & 0 & 1 & 1 \\
\hline 9 & 57 & 53 & 2 & 0 & 0 & 3 & 1 & 0 & 0 & 0 & 0 & 0 \\
\hline 10 & 60 & 98 & 1 & 0 & 2 & 2 & 0 & 0 & 0 & 0 & 0 & 0 \\
\hline 11 & 63 & 67 & 0 & 0 & 1 & 3 & 0 & 0 & 0 & 1 & 0 & 0 \\
\hline 12 & 31 & 53 & 2 & 1 & 2 & 2 & 1 & 1 & 0 & 0 & 1 & 0 \\
\hline 13 & 39 & 67 & 1 & 1 & 3 & 2 & 1 & 0 & 0 & 0 & 0 & 1 \\
\hline 14 & 74 & 39 & 0 & 0 & 1 & 1 & 0 & 1 & 0 & 0 & 0 & 1 \\
\hline 15 & 75 & 81 & 2 & 1 & 1 & 3 & 0 & 1 & 0 & 0 & 1 & 0 \\
\hline 16 & 46 & 26 & 1 & 0 & $\frac{1}{1}$ & 1 & 0 & $\frac{1}{0}$ & 0 & 1 & $\frac{1}{0}$ & 0 \\
\hline 17 & 33 & 41 & 1 & 0 & 2 & 4 & 0 & 0 & 0 & 0 & 0 & 0 \\
\hline 18 & 59 & 36 & $\frac{1}{2}$ & 0 & $\frac{2}{2}$ & $\frac{7}{1}$ & 0 & 0 & 0 & 0 & 0 & 1 \\
\hline 19 & 63 & 35 & 2 & 0 & 1 & 2 & 0 & 0 & 1 & 0 & 0 & 0 \\
\hline 20 & 68 & 62 & 1 & 0 & 2 & 2 & 1 & 0 & 1 & 0 & 0 & 0 \\
\hline 21 & 77 & 101 & 1 & 1 & 3 & 4 & 1 & 1 & 1 & 0 & 0 & 0 \\
\hline 22 & 71 & 61 & 1 & 0 & 0 & 3 & 0 & 1 & 0 & 1 & 1 & 0 \\
\hline 23 & 64 & 16 & 1 & 0 & 0 & 0 & 0 & 1 & 0 & 0 & 1 & 0 \\
\hline 24 & 88 & 30 & 0 & 0 & 1 & 2 & 0 & 0 & 1 & 0 & 0 & 0 \\
\hline 25 & 79 & 35 & 0 & 0 & 0 & 1 & 1 & 0 & 0 & 1 & 0 & 1 \\
\hline 26 & 74 & 27 & 2 & 2 & 0 & 1 & 0 & 1 & 0 & 0 & 0 & 0 \\
\hline 27 & 66 & 50 & 1 & 3 & 0 & 2 & 0 & 1 & 0 & 0 & 1 & 0 \\
\hline 28 & 58 & $\begin{array}{ll}17 \\
\end{array}$ & 0 & 0 & 0 & 0 & 0 & 0 & 1 & 0 & $\frac{1}{1}$ & 0 \\
\hline 29 & 81 & 19 & 0 & 0 & 0 & 0 & 1 & 0 & 0 & 0 & 1 & 0 \\
\hline 30 & 67 & 125 & 2 & 1 & 2 & 5 & 0 & 1 & 1 & 2 & 0 & 0 \\
\hline 31 & 53 & 47 & 1 & 2 & 1 & 2 & 0 & 0 & 1 & 0 & 0 & 0 \\
\hline 32 & 38 & 34 & 1 & 0 & 1 & 1 & 0 & 0 & 1 & 0 & 0 & 1 \\
\hline 33 & 55 & 25 & 0 & 1 & 0 & 1 & 0 & 0 & 0 & 0 & 0 & 0 \\
\hline
\end{tabular}




\begin{tabular}{|c|c|c|c|c|c|c|c|c|c|c|c|c|}
\hline $\begin{array}{l}\text { Project } \\
\text { number }\end{array}$ & $\begin{array}{l}\text { Value } \\
\text { added } \\
\text { time } \\
\text { of the } \\
\text { project } \\
(\mathrm{VA} / \mathrm{T})\end{array}$ & $\begin{array}{l}\text { waste } \\
\text { time }\end{array}$ & Waiting & $\begin{array}{c}\text { Transport/ } \\
\text { handoffs }\end{array}$ & Movement & $\begin{array}{c}\text { Over } \\
\text { processing }\end{array}$ & Inventory & $\begin{array}{l}\text { Overproduction/un- } \\
\text { synchronized } \\
\text { processing }\end{array}$ & Defects & Reinvention & $\begin{array}{l}\text { Lack of } \\
\text { discipline }\end{array}$ & $\begin{array}{l}\text { Limited } \\
\text { IT } \\
\text { resources }\end{array}$ \\
\hline 34 & 53 & 73 & 1 & 0 & 1 & 3 & 2 & 1 & 0 & 0 & 0 & 0 \\
\hline 35 & 72 & 103 & 1 & 0 & 3 & 3 & 1 & 0 & 0 & 1 & 1 & 1 \\
\hline 36 & 61 & 79 & 1 & 2 & 1 & 2 & 1 & 0 & 0 & 1 & 0 & 1 \\
\hline 37 & 58 & 27 & 0 & 1 & 0 & 1 & 0 & 0 & 1 & 0 & 0 & 0 \\
\hline 38 & 74 & 56 & 1 & 0 & 1 & 1 & 0 & 0 & 0 & 0 & 0 & 0 \\
\hline 39 & 76 & 24 & 1 & 0 & 0 & 0 & 0 & 0 & 0 & 1 & 0 & 0 \\
\hline 40 & 79 & 91 & 0 & 2 & 0 & 2 & 0 & 0 & 0 & 0 & 0 & 1 \\
\hline
\end{tabular}

Table 13(b). Waste time and type of "wastes"

Journal of Industrial Engineering and Management, 2014 (www.jiem.org)

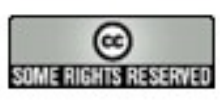

Article's contents are provided on a Attribution-Non Commercial 3.0 Creative commons license. Readers are allowed to copy, distribute and communicate article's contents, provided the author's and Journal of Industrial Engineering and Management's names are included. It must not be used for commercial purposes. To see the complete license contents, please visit http://creativecommons.org/licenses/by-nc/3.0/. 